\title{
Hypothalamic-pituitary-adrenal (HPA) axis suppression after treatment with glucocorticoid therapy for childhood acute lymphoblastic leukaemia (Review)
}

Gordijn MS, Gemke RJBJ, van Dalen EC, Rotteveel J, Kaspers GJL

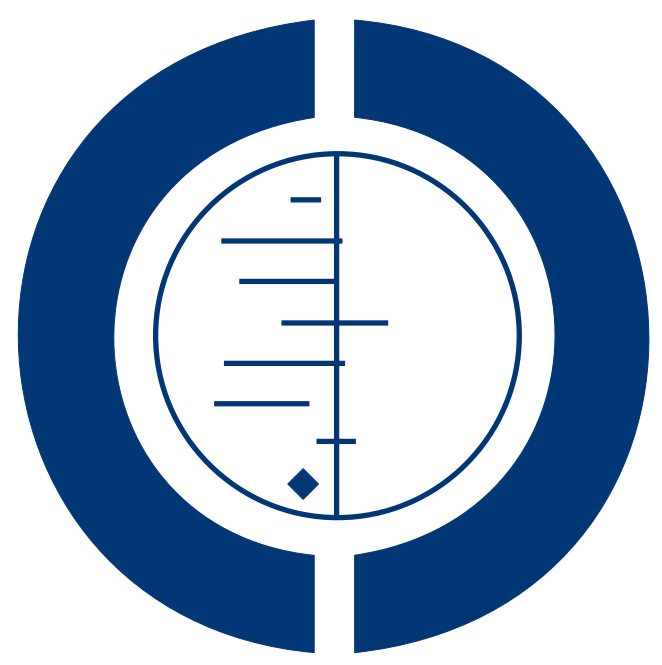

\section{THE COCHRANE COLLABORATION ${ }^{\circledR}$}

This is a reprint of a Cochrane review, prepared and maintained by The Cochrane Collaboration and published in The Cochrane Library 2012, Issue 5

http://www.thecochranelibrary.com

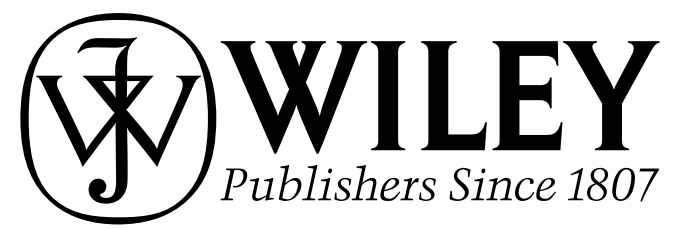

Hypothalamic-pituitary-adrenal (HPA) axis suppression after treatment with glucocorticoid therapy for childhood acute lymphoblastic leukaemia (Review)

Copyright $\odot 2012$ The Cochrane Collaboration. Published by John Wiley \& Sons, Ltd. 
TABLE OF CONTENTS

HEADER . . . . . . . . . . . . . . . . . . . . . . . . . . . . . . . . . . . . . . . 1

ABSTRACT . . . . . . . . . . . . . . . . . . . . . . . . . . . . . . . . . . . . . . . . . . . . . . .

PLAIN LANGUAGE SUMMARY . . . . . . . . . . . . . . . . . . . . . . . . . . . . . . . . . . . 2

BACKGROUND . . . . . . . . . . . . . . . . . . . . . . . . . . . . . . . . . . . . . .

OBJECTIVES . . . . . . . . . . . . . . . . . . . . . . . . . . . . . . . . . . . . . .

METHODS . . . . . . . . . . . . . . . . . . . . . . . . . . . . . . . . . . . . . . 3

RESULTS . . . . . . . . . . . . . . . . . . . . . . . . . . . . . . . . . . . . . 5

Figure 1. . . . . . . . . . . . . . . . . . . . . . . . . . . . . . . . . . . . . 7

Figure 2. . . . . . . . . . . . . . . . . . . . . . . . . . . . . . . . . . . . . . . . . . . 9

DISCUSSION . . . . . . . . . . . . . . . . . . . . . . . . . . . . . . . . . . . . . . . . . . . . . . .

AUTHORS' CONCLUSIONS . . . . . . . . . . . . . . . . . . . . . . . . . . . . . . . . . . . .

ACKNOWLEDGEMENTS . . . . . . . . . . . . . . . . . . . . . . . . . . . . . . . . . . .

REFERENCES . . . . . . . . . . . . . . . . . . . . . . . . . . . . . . . . . . . . . . 11

CHARACTERISTICS OF STUDIES . . . . . . . . . . . . . . . . . . . . . . . . . . . . . . . . . . . . . .

DATA AND ANALYSES . . . . . . . . . . . . . . . . . . . . . . . . . . . . . . . . . . . . . . . . . 20

ADDITIONAL TABLES . . . . . . . . . . . . . . . . . . . . . . . . . . . . . . . . . . . 20

APPENDICES . . . . . . . . . . . . . . . . . . . . . . . . . . . . . . . . . . . . . . 26

HISTORY . . . . . . . . . . . . . . . . . . . . . . . . . . . . . . . . . . . . . . . . 30

CONTRIBUTIONS OF AUTHORS . . . . . . . . . . . . . . . . . . . . . . . . . . . . . . . . . . . . . . . . . .

DECLARATIONS OF INTEREST . . . . . . . . . . . . . . . . . . . . . . . . . . . . . . . . . . . .

SOURCES OF SUPPORT . . . . . . . . . . . . . . . . . . . . . . . . . . . . . . . . . . . . . . . . . . . . . .

DIFFERENCES BETWEEN PROTOCOL AND REVIEW . . . . . . . . . . . . . . . . . . . . . . . . . . . . 31

INDEX TERMS . . . . . . . . . . . . . . . . . . . . . . . . . . . . . . . . . . . . 31

Hypothalamic-pituitary-adrenal (HPA) axis suppression after treatment with glucocorticoid therapy for childhood acute lymphoblastic leukaemia (Review)

Copyright $\odot 2012$ The Cochrane Collaboration. Published by John Wiley \& Sons, Ltd. 


\title{
[Intervention Review]
}

\section{Hypothalamic-pituitary-adrenal (HPA) axis suppression after treatment with glucocorticoid therapy for childhood acute lymphoblastic leukaemia}

\author{
Maartje S Gordijn ${ }^{1}$, Reinoud JBJ Gemke ${ }^{2}$, Elvira C van Dalen ${ }^{3}$, Joost Rotteveel ${ }^{4}$, Gertjan JL Kaspers 5 \\ ${ }^{1}$ Department of Pediatrics, Division of Oncology/Hematology, VU University Medical Center, Amsterdam, Netherlands. ${ }^{2}$ Department \\ of Pediatrics, Division of General Pediatrics and other subspecialties, VU University Medical Center, Amsterdam, Netherlands. \\ ${ }^{3}$ Department of Paediatric Oncology, Emma Children's Hospital / Academic Medical Center, Amsterdam, Netherlands. ${ }^{4}$ Department \\ of Pediatrics, Division of Endocrinology, VU University Medical Center, Amsterdam, Netherlands. ${ }^{5}$ Department of Paediatrics, Divi- \\ sion of Paediatric Oncology/Haematology, VU University Medical Center, Amsterdam, Netherlands \\ Contact address: Maartje S Gordijn, Department of Pediatrics, Division of Oncology/Hematology, VU University Medical Center, \\ PO Box 7057, Amsterdam, 1007 MB, Netherlands. ms.gordijn@vumc.nl.
}

Editorial group: Cochrane Childhood Cancer Group.

Publication status and date: New, published in Issue 5, 2012.

Review content assessed as up-to-date: 18 January 2011.

Citation: Gordijn MS, Gemke RJBJ, van Dalen EC, Rotteveel J, Kaspers GJL. Hypothalamic-pituitary-adrenal (HPA) axis suppression after treatment with glucocorticoid therapy for childhood acute lymphoblastic leukaemia. Cochrane Database of Systematic Reviews 2012, Issue 5. Art. No.: CD008727. DOI: 10.1002/14651858.CD008727.pub2.

Copyright (C) 2012 The Cochrane Collaboration. Published by John Wiley \& Sons, Ltd.

\begin{abstract}
A B S T R A C T
Background

Glucocorticoids play a major role in the treatment of acute lymphoblastic leukaemia (ALL). However, supraphysiological doses may cause suppression of the hypothalamic-pituitary-adrenal (HPA) axis. HPA axis suppression resulting in reduced cortisol response may cause an impaired stress response and an inadequate host defence against infections, which remains a cause of morbidity and death. The exact occurrence and duration of HPA axis suppression after glucocorticoid therapy for childhood ALL are unclear.
\end{abstract}

\section{Objectives}

To examine the occurrence and duration of HPA axis suppression after (each cycle of) glucocorticoid therapy for childhood ALL.

\section{Search methods}

We searched the Cochrane Central Register of Controlled Trials (in The Cochrane Library, issue 3, 2010), MEDLINE/PubMed (from 1945 to July 2010) and EMBASE/Ovid (from 1980 to July 2010). In addition, we searched reference lists of relevant articles, conference proceedings and ongoing trial databases.

\section{Selection criteria}

All study designs, except case reports and patient series with fewer than 10 patients, examining the effect of glucocorticoid therapy for childhood ALL on the HPA axis function.

\section{Data collection and analysis}

Two review authors independently performed the study selection. One review author performed the data extraction and 'Risk of bias' assessment, which was checked by another review author.

Hypothalamic-pituitary-adrenal (HPA) axis suppression after treatment with glucocorticoid therapy for childhood acute lymphoblastic leukaemia (Review)

Copyright $\Subset 2012$ The Cochrane Collaboration. Published by John Wiley \& Sons, Ltd. 


\section{Main results}

We identified seven studies (total number of participants =189), including one randomised controlled trial (RCT), which assessed the adrenal function. None of the studies assessed the HPA axis at the level of the hypothalamus, pituitary, or both. Due to substantial differences between studies, results could not be pooled. All studies had some methodological limitations. The included studies demonstrated that adrenal insufficiency occurs in nearly all patients in the first days after cessation of glucocorticoid treatment for childhood ALL. The majority of patients recovered within a few weeks, but a small amount of patients had ongoing adrenal insufficiency lasting up to 34 weeks. In the RCT, the occurrence and duration of adrenal insufficiency did not differ between the prednisolone and dexamethasone arms. In one study included in the review it appeared that treatment with fluconazole prolonged the duration of adrenal insufficiency.

\section{Authors' conclusions}

Based on the available evidence, we conclude that adrenal insufficiency commonly occurs in the first days after cessation of glucocorticoid therapy for childhood ALL, but the exact duration is unclear. Since no data on the level of the hypothalamus and the pituitary were available we cannot make any conclusions regarding those outcomes. Clinicians should consider prescribing glucocorticoid replacement therapy during periods of serious stress in the first weeks after cessation of glucocorticoid therapy for childhood ALL, to reduce the risk of life-threatening complications. However, more high-quality research is needed for evidence-based guidelines for glucocorticoid replacement therapy.

Special attention should be paid to patients receiving fluconazole therapy, and perhaps similar antifungal drugs, as this may prolong the duration of adrenal insufficiency.

\section{PLAIN LANGUAGE SUMMARY}

Hypothalamic-pituitary-adrenal (HPA) axis suppression after treatment with glucocorticoid therapy for childhood acute lymphoblastic leukaemia

Acute lymphoblastic leukaemia (ALL) is the most frequent type of cancer in children. Glucocorticoids, like prednisone and dexamethasone, play a major role in the treatment of ALL. However, high-dose glucocorticoids may cause HPA axis suppression. Suppression of the HPA axis, resulting in inadequate cortisol production, may cause an impaired response to stressors (e.g. trauma, surgery or inflammation) and an inadequate host defence against infections and remains a cause of morbidity and death in childhood. The occurrence and duration of HPA axis suppression after glucocorticoid therapy for childhood ALL are unclear.

This systematic review included six cohort studies and one randomised study, which assessed the adrenal function. None of the studies assessed the HPA axis at the level of the hypothalamus, pituitary, or both. All studies had some methodological limitations and results could not be pooled because of the heterogeneity. Adrenal insufficiency occurred in nearly all of the patients in the first days after cessation of glucocorticoid therapy. The majority of patients recovered within a few weeks, but a small number of patients had ongoing adrenal insufficiency lasting up to 34 weeks. More high-quality research is needed to assess the exact occurrence and duration of HPA axis suppression in order to formulate adequate guidelines for glucocorticoid replacement therapy.

\section{B A C K G R O U N}

Of all malignancies in children, acute lymphoblastic leukaemia (ALL) is the most frequent type. Annually, approximately 120 children with ALL are newly diagnosed in the Netherlands (DCOG 2008). Since treatment and survival rates of childhood ALL have substantially improved over time, morbidity and mortality due to treatment-related side effects become increasingly important.
Unfortunately, up to $5 \%$ of children die because of the toxic side effects of treatment, and this percentage becomes even greater in higher-risk subgroups. The main cause of this treatment-related mortality is infection associated with cytotoxic and immunosuppressive drugs (Christensen 2005; Pruckner 2009; Rubnitz 2004; Wheeler 1996). Glucocorticoid therapy is an important contributing factor to the occurrence and severity of infection (Te Poele 
2007). In addition, several studies report an increase in sepsis and lethal infections in children with ALL since prednisone has been substituted for the more potent glucocorticoid dexamethasone (Hurwitz 2000; Igarashi 2005; Te Poele 2007).

Glucocorticoids play a major role in the treatment of ALL. They induce apoptosis of the lymphoblastic cells (Planey 2000). Children with ALL receive cyclic courses of high-dose glucocorticoids, like prednisone (or prednisolone) and dexamethasone. However, supraphysiological doses of glucocorticoids may suppress hypothalamic secretion of corticotrophin-releasing hormone (CRH) and of adrenocorticotropic hormone (ACTH) by the pituitary gland, resulting in secondary adrenal cortex atrophy with delayed recovery of hypothalamic-pituitary-adrenal (HPA) axis function. In states of profound or prolonged ACTH deficiency, the adrenal glands may temporarily be unable to generate sufficient cortisol (Henzen 2000; Krasner 1999). Supraphysiological glucocorticoid therapy is the most common cause of secondary adrenal insufficiency (Shulman 2007). The HPA axis plays a major role in the stress response and host defence against infection. Stressors such as trauma, surgery or inflammation stimulate the HPA axis, leading to an increase in cortisol production. In turn, increased cortisol levels cause anti-inflammatory effects and inhibition of proinflammatory cytokines (Hettmannsperger 1992; Nyhlén 2000; Waage 1988). Suppression of the HPA axis resulting in reduced adrenal cortisol production represents an impaired stress response and an inadequate host defence against infections and remains a cause of morbidity and death in childhood (Shulman 2007).

There are different well-established tests of HPA axis function. Morning serum cortisol value reflects basal adrenal function but gives no indication of the capacity to respond to stress (Agwu 1999; Schlaghecke 1992). Stimulation tests are used to assess the HPA axis response to stress. The insulin-tolerance-test is considered the most reliable test to evaluate the HPA axis function at the level of the pituitary and the adrenal gland, but is associated with potentially dangerous side effects (Shah 1992). The CRH stimulation test is only indicated in patients with a central disorder of the HPA axis (Maghnie 2005; Van Tijn 2008). The glucagon test has also been proven to be a safe and reliable method for testing HPA axis function at the level of the pituitary and the adrenal gland, but may also induce mild inadvertent side effects (Böttner 2005; Rao 1987; Vanderschueren-Lodeweyckx 1974). A well-established alternative to test the HPA axis at the level of the adrenal gland without undesirable side effects is the low-dose (1 $\mu \mathrm{g})$ ACTH stimulation test. This test is able to detect more subtle degrees of adrenal atrophy caused by central adrenal insufficiency compared to the "normal" ACTH stimulation test $(250 \mu \mathrm{g})$. The results of the low-dose ACTH test closely correlate with those of the insulin-tolerance-test (Abdu 1999; Dickstein 1997; Tjordman 2000).

Several studies have prospectively assessed HPA axis function following high-dose glucocorticoids during treatment for ALL.
Adrenal stimulation tests have been performed and repeated until cortisol levels normalised. The majority of patients seem to recover in a few weeks but prolonged suppression may occur, lasting over several months in some cases (Einaudi 2008; Mahachoklertwattana 2004; Rix 2005). Since children with ALL plus HPA axis suppression suffering from fever or other stressors may benefit from glucocorticoid replacement therapy (e.g. hydrocortisone), it is important to derive a consistent picture of HPA axis impairment after corticosteroid therapy.

Our aim was to undertake a systematic review of the HPA axis function after glucocorticoid therapy for childhood ALL. On this basis, adequate guidelines for glucocorticoid substitution can be formulated and implemented to reduce the risk of infection in childhood ALL.

\section{O B J E C T I VES}

\section{Primary objective}

- To examine the occurrence of HPA axis suppression after (each cycle of) glucocorticoid therapy for childhood ALL.

- To examine the duration of HPA axis suppression after treatment with glucocorticoids for childhood ALL.

\section{Secondary objectives}

To examine whether the HPA axis function after administration of glucocorticoids is dependent on:

- the moment of testing after cessation of glucocorticoid therapy

- the (cumulative) dose of glucocorticoids

- the type of glucocorticoids; prednisone, prednisolone or dexamethasone

- the duration of glucocorticoid therapy

- the method of cessation of glucocorticoid therapy; abrupt or gradual

\section{METHODS}

\section{Criteria for considering studies for this review}

\section{Types of studies}

All study designs, except case reports and patient series with fewer than 10 patients, examining the effect of glucocorticoid therapy 
for childhood ALL on HPA axis function. This effect can be evaluated both during treatment for ALL (after cessation of a glucocorticoid course) and after the end of all ALL treatment. Discrepancies concerning the definition of a cohort study between review authors were resolved by consensus. No third party arbitration was needed.

\section{Types of participants}

Patients who were treated with glucocorticoids for ALL between the age of 0 and 18 years, irrespective of the duration of followup after the end of glucocorticoid therapy. Exclusion criteria are cranial radiotherapy, since this may damage the HPA axis, and testing HPA axis function by a CRH stimulation test only, since this test is only indicated in patients with a central disorder of the HPA axis (Maghnie 2005; Van Tijn 2008).

\section{Types of interventions}

Glucocorticoid therapy (prednisone, prednisolone, dexamethasone) during treatment for ALL. The intervention was not compared to a control group, since this was not available (with the exception of the included randomised controlled trials (RCT)).

\section{Types of outcome measures}

HPA axis function, measured by early morning plasma cortisol levels (between 8 and 10 a.m.) or by stimulation tests (e.g. (lowdose) ACTH stimulation test or glucagon stimulation test). We used the cut-off limit as defined by the authors of the original studies.

\section{Search methods for identification of studies}

See: Cochrane Childhood Cancer Group methods used in reviews (Module CCG).

The objective of the literature search was to identify all studies, except case reports and case series, reporting on HPA axis function after glucocorticoid therapy for childhood ALL.

\section{Electronic searches}

We searched the following electronic databases: the Cochrane Central Register of Controlled Trials (CENTRAL) (in The Cochrane Library, issue 3, 2010), MEDLINE/PubMed (from 1945 to July 2010) and EMBASE/Ovid (from 1980 to July 2010). The search strategies for the different electronic databases (using a combination of controlled vocabulary and text words) are shown in the appendices (Appendix 1, Appendix 2, Appendix 3).

\section{Searching other resources}

We located information about trials not registered in CENTRAL, MEDLINE or EMBASE, either published or unpublished, by searching the reference lists of relevant articles and review articles. We handsearched the conference proceedings of the International Society for Paediatric Oncology (SIOP) (from 2005 to 2009) and the American Society of Clinical Oncology (ASCO) (from 2005 to 2009). For the search strategy see Appendix 4.

We also scanned the International Standard Randomized Controlled Trial Number (ISRCTN) register and the National Institutes of Health (NIH) register for ongoing trials: http:// www.controlled-trials.com (both screened July 2010; for the search strategy see Appendix 5).

We imposed no language restrictions. We will update the searches every 2 years.

\section{Data collection and analysis}

\section{Selection of studies}

After performing the search strategy, two review authors independently selected studies meeting the inclusion criteria. Discrepancies between review authors were resolved by consensus. No third party arbitration was needed. We obtained in full any study that seemed to meet the inclusion criteria on grounds of the title or abstract or both, for closer inspection. We clearly stated reasons for exclusion of any study considered for this review.

\section{Data extraction and management}

Data extraction was performed by one review author using standardised forms and checked by another review author. The review authors were not blinded to the journal, the authors or the institution. We extracted data on the following categories: study characteristics, participants, interventions, outcome measures, length of follow-up, risk factors, and 'Risk of bias' assessment.

Discrepancies between authors were resolved by consensus. No third party arbitration was needed.

\section{Assessment of risk of bias in included studies}

The assessment of risk of bias was based on previously described checklists for observational studies according to Evidence-Based Medicine Criteria (Grimes 2002; Laupacis 1994). The assessment of risk of bias of the included studies was performed by one review author and checked by another review author. The 'Risk of bias' assessment criteria for observational studies are described in Table 1. For RCTs we used the 'Risk of bias' items as described in the module of the Childhood Cancer Group, which are based on the Cochrane Handbook for Systematic Reviews of Interventions (Higgins 2009; Module CCG) (see Table 2). Discrepancies between review 
authors were resolved by consensus. No third party arbitration was needed.

\section{Measures of treatment effect}

Prevalence of HPA axis suppression at several follow-up time points and time duration of HPA axis suppression.

\section{Dealing with missing data}

We contacted authors of individual studies for clarification of unclear data or to obtain missing data regarding selection of studies, the 'Risk of bias' assessment and data extraction.

\section{Assessment of heterogeneity}

We planned to assess heterogeneity both by visual inspection of the forest plots and by a formal statistical test for heterogeneity, that is the $\mathrm{I}^{2}$ statistic. However, since we were not able to pool the results of the included studies, this was not applicable.

\section{Assessment of reporting biases}

We planned to use a funnel plot to quantify the potential presence of publication bias. However, since we were not able to pool the results of the included studies, this was not applicable.

\section{Data synthesis}

We planned to perform analyses using the statistical software Comprehensive Meta Analysis (Biostat, Inc, USA).

Across the various studies, we planned to conduct a multivariate linear meta-regression analysis model with a backwards selection strategy $(\mathrm{P}<0.10)$ to examine the relation between potential predictive factors and HPA axis suppression.

However, since we were not able to pool the results of the included studies, this was not applicable and we described the results of the individual studies separately. Kaplan-Meier curves were calculated using SPSS version 15.0.

\section{Sensitivity analysis}

We planned to perform a sensitivity analysis for the used 'Risk of bias' assessment criteria. However, since we were not able to pool the results of the included studies, this was not applicable.

\section{RES U L T S}

\section{Description of studies}

See: Characteristics of included studies; Characteristics of excluded studies.

See: Characteristics of included studies; Characteristics of excluded studies.

\section{Results of the search}

Running the searches in the electronic databases of CENTRAL, MEDLINE/PubMed and EMBASE/Ovid revealed a total of 1388 references. Initial screening of the titles and abstracts excluded 1375 references that clearly did not fulfil all criteria for considering studies for this review. Of the remaining 13 references we examined the full-text articles. Seven of the 13 full-text articles were eligible for inclusion in this systematic review, whereas the other six were not. The reasons for exclusion are illustrated in Characteristics of excluded studies.

Scanning the reference list of relevant articles and reviews did not identify any additional eligible studies.

Scanning the conference proceedings of SIOP and ASCO did not identify any eligible studies and scanning the ongoing trials databases did not identify any ongoing studies.

In summary, seven articles could be included in this review. We made attempts to contact authors to clarify aspects of the study design and data analysis. Characteristics of the included studies are summarised in the Characteristics of included studies table.

\section{Included studies}

All included studies evaluated adrenal function after glucocorticoid therapy for childhood ALL. None of the studies assessed the HPA axis at the level of the hypothalamus, pituitary or both. The total number of patients included in the studies was 189 . The seven included studies examined the adrenal function after different types, doses and durations of glucocorticoid therapy and after different methods of cessation of glucocorticoid therapy. Three studies examined the effect of dexamethasone on adrenal function (Cunha 2004; Felner 2000; Kuperman 2001) and four studies evaluated the effect of both dexamethasone and predniso(lo)ne on adrenal function (Einaudi 2008; Mahachoklertwattana 2004; Petersen 2003; Rix 2005). Adrenal function was measured by early morning plasma cortisol levels (between 8 and 10 a.m.) (Cunha 2004; Kuperman 2001) or by the (low-dose) ACTH stimulation test (Einaudi 2008; Felner 2000; Mahachoklertwattana 2004; Petersen 2003; Rix 2005). Four studies performed follow-up tests until normalisation of adrenal function (Einaudi 2008; Felner 2000; Mahachoklertwattana 2004; Petersen 2003), for the other three studies the follow-up lengths were 1 month, 2 weeks and 2 to 7 days, respectively (Cunha 2004; Kuperman 2001; Rix 2005). Six of the seven identified studies were observational studies (Cunha 2004; Felner 2000; Kuperman 2001; Mahachoklertwattana 2004; Petersen 2003; Rix 2005) and one was an RCT evaluating prednisolone versus dexamethasone (both treatment groups received prednisolone prior to randomisation) (Einaudi 2008). 


\section{Excluded studies}

Information on the six studies excluded during examination of the full-text articles is included in the Characteristics of excluded studies table. The most common reasons for exclusion were cranial irradiation therapy or the lack of (adequate) HPA axis function tests.

\section{Risk of bias in included studies}

\section{Cohort studies}

For the evaluation of the 'internal validity' of the six included cohort studies we assessed the risk of selection bias, attrition bias, detection bias and confounding that was present in the included studies. Based on additional information provided by the authors, there was a low risk of selection bias (based on the representativeness of the study group) in four of the six studies as the study group consisted of more than $90 \%$ of the original cohort (Felner 2000; Kuperman 2001; Petersen 2003; Rix 2005). According to additional information provided by the authors, one study selected an unrepresentative study group of about $30 \%$ of the original cohort (Cunha 2004). For another study neither the article nor the correspondence with the author provided information on the selection of the participants (Mahachoklertwattana 2004). The risk of attrition bias (based on the completeness of follow-up) was low in all six studies as the outcome was assessed for $60 \%$ to $90 \%$ of the study group at the end date of the study (Cunha 2004; Felner 2000; Kuperman 2001; Mahachoklertwattana 2004; Petersen 2003; Rix 2005). Additional information provided by the authors of one study reported that the outcome assessor was not blinded (Rix 2005). None of the other studies provided information on the blinding of the outcome assessor to glucocorticoid treatment, so detection bias could not be ruled out. In five studies, confounding (based on important risk factors and follow-up that were taken into account) might have been present (Cunha 2004; Felner 2000; Kuperman 2001; Mahachoklertwattana 2004; Rix 2005). In one study, fluconazole therapy as a risk factor for the development of adrenal insufficiency was taken into account (Petersen 2003).

For the evaluation of the 'external validity' of the included cohort studies we assessed the risk of reporting bias. In four studies, the study group was well defined in terms of treatment protocol and (cumulative) dose, type, duration and form of cessation of glucocorticoid treatment (Cunha 2004; Mahachoklertwattana 2004; Petersen 2003; Rix 2005). Two studies did not mention the treatment protocol (Felner 2000; Kuperman 2001). In all six studies the follow-up was well defined as the length of follow-up and the frequency of measuring was mentioned (Cunha 2004; Felner 2000; Kuperman 2001; Mahachoklertwattana 2004; Petersen 2003; Rix 2005). In these studies the outcome was well defined and the methods of detection were described and the outcome definition was objective and precise (Cunha 2004; Felner 2000; Kuperman 2001; Mahachoklertwattana 2004; Petersen 2003; Rix 2005). The risk estimation (based on the calculation of relative risk, odds ratio, attributable risk, linear or logistic regression model, mean difference, or $\mathrm{Chi}^{2}$ statistic) was well defined in five of the six studies (Cunha 2004; Felner 2000; Kuperman 2001; Mahachoklertwattana 2004; Rix 2005).

See also Table 3.

\section{Randomised controlled trial}

For the included RCT we evaluated the risk of selection bias, performance bias, detection bias, attrition bias, reporting bias and other biases. Based on additional information provided by the authors, no selection bias (based on sequence generation and concealment of allocation) was present (Einaudi 2008). Performance bias (based on the blinding of care providers and participants) and detection bias (based on the blinding of the outcome assessors) could not be ruled out (Einaudi 2008). The RCT was susceptible for reporting bias as not all of the study's pre-specified primary outcomes were reported (Einaudi 2008). The risk on attrition bias (based on the completeness of outcome data) or other bias (i.e. based on potential source of bias related to the specific study design, premature termination of the study due to some data-dependent process, extreme baseline imbalance) in the RCT was low (Einaudi 2008).

See also Table 4.

\section{Effects of interventions}

\section{Adrenal insufficiency (occurrence and duration)}

Data on the prevalence and the duration of adrenal insufficiency after treatment with glucocorticoid therapy for childhood ALL could be extracted from all included studies. However, it should be noted that the individual studies used different types and (cumulative) doses of glucocorticoids. In addition, differences in duration and method of cessation of glucocorticoid therapy occurred. Methods of testing adrenal function varied as well. Due to this heterogeneity pooling of results was not possible. For more information see Characteristics of included studies.

Two studies used the ACTH stimulation test with comparable cut-off limits (stimulated cortisol: $18 \mu \mathrm{g} / \mathrm{dL}(500 \mathrm{nmol} / \mathrm{L}))$ for measuring adrenal function (Felner 2000; Petersen 2003). Before glucocorticoid therapy, adrenal function was normal in all patients in the study of Felner 2000. However, all 10 patients (100\%) had insufficient cortisol levels 1 day after abrupt cessation of 28 days of dexamethasone at $6 \mathrm{mg} / \mathrm{m}^{2} /$ day. Three out of 10 patients (30\%) had ongoing adrenal insufficiency after 4 weeks but all recovered after 8 weeks. In the study of Petersen 2003, two types of glucocorticoid therapy were assessed; induction therapy comprising 35 days of prednisolone $60 \mathrm{mg} / \mathrm{m}^{2} /$ day with tapering over 9 days and re-induction therapy comprising 21 days of dexamethasone $10 \mathrm{mg} / \mathrm{m}^{2} /$ day with tapering over 9 days. Re-induction therapy succeeded induction therapy, thus patients in the dexamethasone group also received induction therapy with prednisolone. HPA axis function was not assessed before glucocorticoid therapy. Af- 
ter induction therapy $(\mathrm{n}=10)$, seven out of 10 patients $(70 \%)$ had adrenal insufficiency within the first week. Six patients $(60 \%)$ had ongoing adrenal insufficiency after 3 weeks and four patients (40\%) after 7 weeks. These four patients remained insufficient at the end of their follow-up, that is after 10,11, 11 and 19 weeks, respectively. The latter patient, with no recovery by 19 weeks, received, in addition to the induction therapy, two 1-week long reinduction courses including prednisolone $60 \mathrm{mg} / \mathrm{m}^{2} /$ day during adrenal insufficiency. After re-induction therapy $(n=7)$, five out of seven patients $(71 \%)$ had adrenal insufficiency within the first week. Four patients (57\%) had ongoing adrenal insufficiency af- ter 3 weeks and three patients (43\%) after 7 weeks. These three patients remained insufficient at the end of their follow-up, that is after 16, 33 and 34 weeks, respectively. One of these patients, with no recovery after 16 weeks, received an additional 1-week long reinduction course of prednisolone $60 \mathrm{mg} / \mathrm{m}^{2} /$ day during the period of adrenal insufficiency. The other two patients, with no recovery after 33 and 34 weeks, received three additional 1-week long reinduction courses including prednisolone $60 \mathrm{mg} / \mathrm{m}^{2} /$ day during adrenal insufficiency. See Table 5 for an overview and Figure 1 for the Kaplan-Meier curve of the prevalence and duration of adrenal insufficiency in the studies that used an ACTH suppression test.

Figure I. Kaplan-Meier estimate of prevalence and duration of adrenal insufficiency after treatment with glucocorticoid therapy for childhood acute lymphoblastic leukaemia based on ACTH stimulation tests.

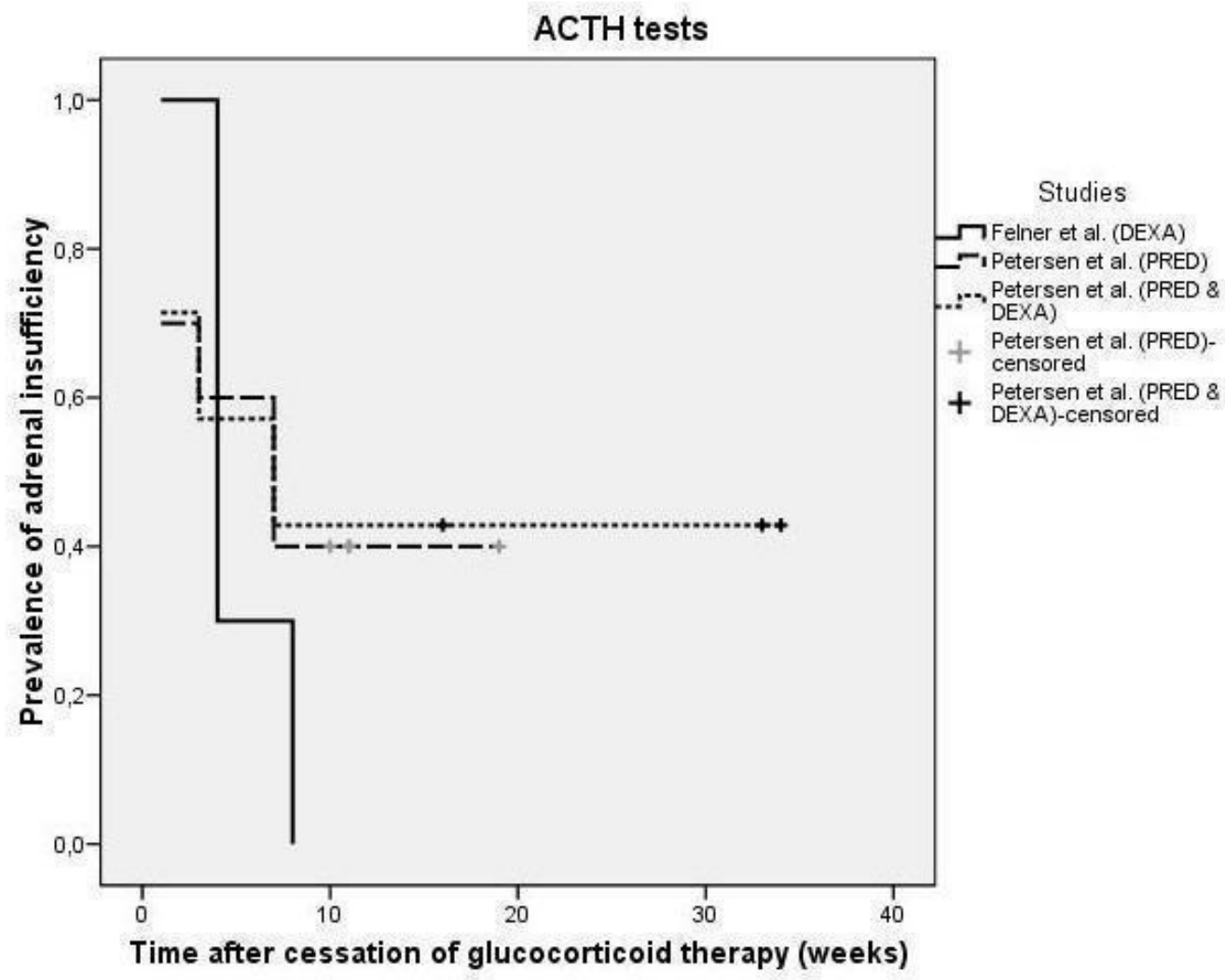

Hypothalamic-pituitary-adrenal (HPA) axis suppression after treatment with glucocorticoid therapy for childhood acute lymphoblastic leukaemia (Review)

Copyright $\odot 2012$ The Cochrane Collaboration. Published by John Wiley \& Sons, Ltd. 
Three studies used the low-dose ACTH stimulation test with comparable cut-off limits (stimulated cortisol: $18 \mu \mathrm{g} / \mathrm{dL}$ (500 nmol/ L)) for measuring adrenal function (Mahachoklertwattana 2004; Rix 2005; Einaudi 2008). In the study of Mahachoklertwattana 2004 all patients received induction therapy with prednisolone 40 $\mathrm{mg} / \mathrm{m}^{2} /$ day. Four weeks after its completion this was followed by maintenance therapy every 4 weeks consisting of 7 days of dexamethasone $8 \mathrm{mg} / \mathrm{m}^{2} /$ day. Baseline cortisol levels before induction therapy and 2 weeks afterwards were not significantly different between the adrenal suppressed and the unsuppressed group. Eleven out of 24 patients $(46 \%)$ had adrenal insufficiency 2 weeks after abrupt cessation of 28 days of induction therapy. Nine patients (38\%) had ongoing adrenal insufficiency after 4 weeks, seven patients (29\%) after 8 weeks and three patients (13\%) after 12 weeks. The latter three patients remained insufficient at the end of followup at 20 weeks.

In the study of Rix 2005, three types of glucocorticoid treatment were evaluated. All patients (standard risk, intermediate risk and high risk) received induction therapy (22 patients in total were tested afterwards; for two patients no information was available) comprising 35 days of prednisolone $60 \mathrm{mg} / \mathrm{m}^{2} /$ day with tapering over 9 days. All patients also received 7-day courses of prednisolone $60 \mathrm{mg} / \mathrm{m}^{2} /$ day without tapering (13 patients in total were tested afterwards) and intermediate-risk and high-risk patients received additionally 21 days of dexamethasone $10 \mathrm{mg} / \mathrm{m}^{2} /$ day with tapering over 9 days ( 7 patients in total were tested afterwards). The 7-day course of prednisolone and the dexamethasone course followed induction therapy. The intermediate-risk group received the dexamethasone course before the 7-day course of prednisolone and the high-risk group received the dexamethasone course after the 7-day course of prednisolone. Based on additional information provided by the authors, 13 patients were tested before induction therapy, and all had a normal adrenal function. Sixteen patients out of $22(73 \%)$ had adrenal insufficiency 1 day after cessation of induction therapy; one of them was lost to follow-up thereafter. Five out of 22 patients (23\%) were not tested at this time point. Eight patients (36\%) had ongoing adrenal insufficiency after 3 days; two of them were lost to follow-up afterwards. Seven patients (32\%) (including the patient that was lost to follow-up) with no confirmed adrenal recovery were not tested at this time point. Eight patients $(36 \%)$ had ongoing adrenal insufficiency at the end of follow-up of 5 days. Three patients (14\%) (i.e., the three patients that were lost to follow-up) with no confirmed adrenal recovery were not tested at this time point. After 7-day courses of prednisolone, all 13 patients $(100 \%)$ remained insufficient at the end of the follow-up period of 2 days. However, two patients out of $13(15 \%)$ already had an insufficient adrenal function before prednisolone therapy. Five patients out of seven (71\%) underwent a low-dose ACTH test before dexamethasone therapy; all patients had sufficient cortisol levels. One day after the dexamethasone course, two out of seven patients (29\%) had adrenal insufficiency; one of them was lost to follow-up thereafter. Five out of seven patients $(71 \%)$ were not tested at this time point. Three patients (43\%) had ongoing adrenal insufficiency after 3 days; one of them was lost to follow-up afterwards. Two patients (29\%) (including the patient that was lost to follow-up) with no confirmed adrenal recovery were not tested at this time point. One patient (14\%) had ongoing adrenal insufficiency at the end of the follow-up period of 7 days. Two patients (29\%) (i.e., the two patients that were lost to follow-up) with no confirmed adrenal recovery were not tested at this time point.

In the study of Einaudi 2008, two randomised arms of glucocorticoid therapy were examined; 22 days of prednisolone $60 \mathrm{mg} /$ $\mathrm{m}^{2} /$ day with tapering over 9 days $(\mathrm{n}=40)$ and 22 days of dexamethasone $10 \mathrm{mg} / \mathrm{m}^{2} /$ day with tapering over 9 days $(\mathrm{n}=24)$. Both groups of patients received 7 days of prednisolone $60 \mathrm{mg} / \mathrm{m}$ $2 /$ day in advance. At diagnosis, basal cortisol values were within the normal range in all patients. In the prednisolone arm, 32 out of 40 patients $(80 \%)$ had adrenal insufficiency 1 day after cessation of glucocorticoid therapy, eight patients (20\%) had ongoing adrenal insufficiency after 7 to 14 days (in the Kaplan Meier curve marked as 14 days) and five patients (13\%) after 28 days. All patients $(100 \%)$ recovered in 10 weeks (in the Kaplan Meier curve marked as 10 weeks). In the dexamethasone arm, 20 out of 24 patients $(83 \%)$ had adrenal insufficiency 1 day after cessation of glucocorticoid therapy. Four patients (17\%) had ongoing adrenal insufficiency after 7 to 14 days (in the Kaplan Meier curve marked as 14 days) and three patients (13\%) after 28 days. All patients $(100 \%)$ recovered in 10 weeks (in the Kaplan Meier curve marked as 10 weeks). See Table 6 for an overview and Figure 2 for the Kaplan-Meier curve of the prevalence and duration of adrenal insufficiency in the studies that used a low-dose ACTH test.

Hypothalamic-pituitary-adrenal (HPA) axis suppression after treatment with glucocorticoid therapy for childhood acute lymphoblastic 
Figure 2. Kaplan-Meier estimate of prevalence and duration of adrenal insufficiency after treatment with glucocorticoid therapy for childhood acute lymphoblastic leukaemia based on low-dose (LD) ACTH stimulation tests.

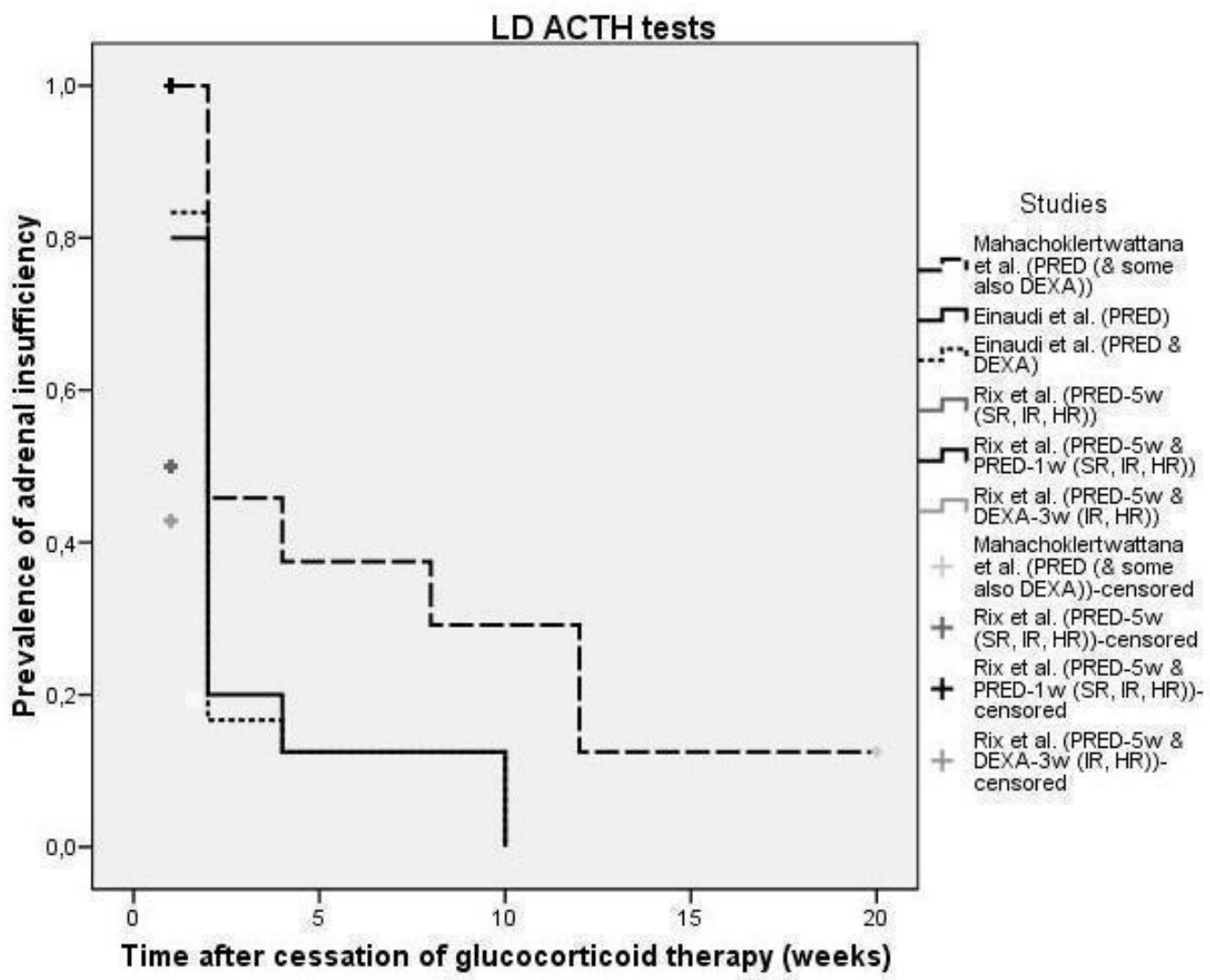

Two studies used basal morning cortisol values for measuring adrenal function. In the study of Cunha 2004, including 35 children, median basal cortisol levels were inhibited on the 8th day $(1.2 \mu \mathrm{g} / \mathrm{dL}$, range 0.9 to $132.7 \mu \mathrm{g} / \mathrm{dL})$ and the 28 th day $(0.9 \mu \mathrm{g} /$ $\mathrm{dL}$, range 0.9 to $6.6 \mu \mathrm{g} / \mathrm{dL}$ ) of 28 days of dexamethasone $6 \mathrm{mg} / \mathrm{m}^{2}$ / day and 48 hours after cessation (over 10 days) of dexamethasone treatment $(2.4 \mu \mathrm{g} / \mathrm{dL}$, range 0.9 to $11.2 \mu \mathrm{g} / \mathrm{dL})$ compared to preglucocorticoid therapy levels $(17.5 \mu \mathrm{g} / \mathrm{dL}$, range 7.6 to $40.9 \mu \mathrm{g} /$ dL) ( $\mathrm{P}=0.01$ for the three tests versus pre-glucocorticoid levels). Median basal cortisol levels 1 month after cessation of dexamethasone treatment $(12.4 \mu \mathrm{g} / \mathrm{dL}$, range 1.8 to $29.0 \mu \mathrm{g} / \mathrm{dL})$, although slightly lower, did not show a significant difference compared with pre-glucocorticoid therapy levels. No data on patient level were available.

In the study of Kuperman 2001, including 15 children, mean basal cortisol levels ( \pm standard error of the mean) were significantly (P

$<0.05)$ lower on day $7(10.8 \pm 1.0 \mu \mathrm{g} / \mathrm{dL})$ and day $14(11.5 \pm 2.0$ $\mu \mathrm{g} / \mathrm{dL}$ ) after abrupt cessation of 42 days of dexamethasone $6 \mathrm{mg} /$ $\mathrm{m}^{2} /$ day than pretreatment $(17.8 \pm 1.3 \mu \mathrm{g} / \mathrm{dL})$. Levels at day 7 and day 14 did not differ significantly. Based on additional information provided by the authors, all patients $(100 \%)$ had sufficient basal cortisol levels at diagnosis $(>7 \mu \mathrm{g} / \mathrm{dL})$, whereas four out of $15(27 \%)$ patients had insufficient basal cortisol levels 7 days after cessation of dexamethasone therapy. One patient was lost to follow-up thereafter. Fourteen days after cessation of dexamethasone therapy, four (29\%) out of 14 patients had insufficient basal cortisol levels. It should be noted that one of them had a sufficient basal cortisol level 7 days earlier. Therefore, these data could not be presented in a Kaplan-Meier curve.

See Table 7 for an overview of the prevalence and duration of adrenal insufficiency in the studies that used basal morning cortisol

Hypothalamic-pituitary-adrenal (HPA) axis suppression after treatment with glucocorticoid therapy for childhood acute lymphoblastic leukaemia (Review)

Copyright $\Subset 2012$ The Cochrane Collaboration. Published by John Wiley \& Sons, Ltd. 
values.

Other outcome measures

Identifying whether the adrenal function after administration of glucocorticoids was dependent on the moment of testing, the (cumulative) dose, type or duration of glucocorticoid therapy or the method of cessation of glucocorticoid therapy was not possible due to the heterogeneity.

\section{DISCUSSION}

With the improvement of survival of childhood ALL, treatmentrelated side effects become increasingly relevant. Glucocorticoids play an important role in the treatment of childhood ALL, but supraphysiological doses may suppress the HPA axis, resulting in an impaired stress response and an inadequate defence against infections (Henzen 2000; Krasner 1999). Patients with HPA axis suppression may benefit from glucocorticoid replacement therapy (e.g. hydrocortisone) to reduce the risk of life-threatening complications. Unfortunately, little information is known on the occurrence and duration of HPA axis suppression and adequate guidelines for glucocorticoid substitution are lacking. This is the first systematic review evaluating HPA axis function after treatment with glucocorticoid therapy for childhood ALL.

We identified seven studies evaluating adrenal function after treatment with glucocorticoid therapy for childhood ALL, including one RCT. None of the studies evaluated the HPA axis at the level of the hypothalamus, pituitary, or both. Due to the substantial differences in types and (cumulative) doses of glucocorticoids used, in duration and method of cessation of glucocorticoid therapy and in method of testing adrenal function, pooling of results was not possible. The included studies demonstrated that adrenal insufficiency occurs in nearly all patients in the first days after cessation of glucocorticoid treatment for childhood ALL. The majority of patients recovered from adrenal insufficiency within 7 weeks. However, a small amount of patients had ongoing adrenal insufficiency lasting up to 34 weeks. At first impression, no significant differences in the occurrence and duration of adrenal insufficiency between different types, (cumulative) doses, durations and methods of cessation of glucocorticoid therapy were present, but due to the heterogeneity between studies we were not able to assess this further. Due to this, and the small patient numbers in the included studies (i.e. low power), definitive conclusions cannot thus not be provided. Only one study was designed as an RCT, enabling comparison between two different types of glucocorticoid therapy; prednisolone versus dexamethasone (Einaudi 2008). Both treatment groups received prednisolone prior to the randomised treatment. The occurrence and duration of adrenal insufficiency did not differ between the treatment arms.

Previous studies demonstrated adrenal suppression after high-dose fluconazole therapy (Albert 2001; Shibata 2001). Only one of the studies that was included in this review, reported on fluconazole therapy (Petersen 2003). In this study, two of the three patients receiving fluconazole had ongoing adrenal insufficiency 8 months after cessation of dexamethasone therapy, whereas the third patient recovered after 3 weeks. It should be taken into account that fluconazole therapy may have influenced the duration of adrenal insufficiency in these patients.

Due to the paucity of RCTs on HPA axis suppression after glucocorticoid therapy in childhood ALL, the majority of studies included in this systematic review were uncontrolled studies. Only one RCT was identified. Due to the lack of control groups it was impossible to evaluate possible causes of HPA axis suppression other than glucocorticoid therapy. Furthermore, all included studies used biochemical markers to evaluate adrenal insufficiency; they did not discuss the clinical consequences of adrenal insufficiency. All included studies had methodological limitations, but currently, this is the best available evidence on this topic.

\section{A U T HOR S' CONCLUSIONS Implications for practice}

Based on the currently available evidence, we can conclude that adrenal insufficiency in the first days after cessation of glucocorticoid therapy for childhood ALL routinely occurs, but the exact duration of adrenal insufficiency remains unclear. Since no data on the level of the hypothalamus and the pituitary were available we cannot make any conclusions regarding those outcomes. The majority of patients seem to recover within 3 days to 7 weeks. However, a small number of patients have prolonged adrenal insufficiency, persisting up to several months. Clinicians should consider prescribing glucocorticoid replacement therapy (e.g. hydrocortisone) during periods of serious stress in the first weeks after cessation of glucocorticoid therapy for childhood ALL, to reduce the risk of life-threatening complications. If replacement therapy is indicated, the beneficial effects and side effects should be evaluated. Until results of adequate future studies on the incidence and duration of HPA axis suppression are available, an HPA axis stimulation test can be recommended, for example, 2 months after cessation of glucocorticoids, to determine if the HPA axis has recovered and if replacement therapy during periods of stress can be discontinued. Exclusively morning cortisol levels are inappropriate to evaluate HPA axis recovery because they only reflect basal cortisol prediction and not the ability of the HPA axis to respond to stress (Agwu 1999).

Special attention should be paid to patients receiving fluconazole therapy, and perhaps similar antifungal drugs, as this may prolong the duration of adrenal insufficiency.

No definitive conclusions regarding differences in the occurrence and duration of adrenal insufficiency between the type (predniso(lo)ne versus dexamethasone), (cumulative) dose, duration 
and method of cessation (abrupt or gradual) of glucocorticoid therapy can be made.

\section{Implications for research}

Studies examining HPA axis suppression after high-dose glucocorticoid therapy for childhood ALL are scarce, especially RCTs. High-quality research regarding the occurrence and duration of HPA axis suppression after glucocorticoid therapy for childhood ALL is needed in order to formulate adequate evidence-based guidelines for glucocorticoid replacement therapy. It will also be of interest to compare the serious adverse effects in patients with, and without, persistent HPA axis suppression. In addition, there is a need for studies evaluating the long-term effects of glucocorticoid therapy on the HPA axis.

Future studies should focus on identifying differences in the effect of type, (cumulative) dose, repeated exposure, duration and method of cessation of glucocorticoid therapy on the occurrence and duration of HPA axis suppression. The number of included patients should be sufficient to obtain the power needed for reliable results.

Furthermore, an interesting and relevant topic for future research would be the (genetic) susceptibility of individuals for HPA axis suppression after glucocorticoid treatment.

\section{ACKNOWLEDGEMENTS}

We thank Edith Leclercq, Trials Search coordinator, for the development of the search strategy and running the searches in CENTRAL, PubMed and EMBASE; Leontien Kremer for her help in preparing the protocol of this review; Peter van de Ven for his statistical advice and the peer reviewers Y. Loke and S. Neggers whose comments have improved this paper. Also, we would like to thank all study authors for providing additional information.

The editorial base of the Cochrane Childhood Cancer Group is funded by Children Cancer-free (KiKa).

\section{R E F E R E N C E S}

\section{References to studies included in this review}

Cunha 2004 \{published data only (unpublished sought but not used)\} Cunha CF, Silva IN, Finch FL. Early adrenocortical recovery after glucocorticoid therapy in children with leukemia. Journal of Clinical Endocrinology and Metabolism 2004;89 (6):2797-802.

Einaudi 2008 \{published data only (unpublished sought but not used)\} Einaudi S, Bertorello N, Masera N, Farinasso L, Barisone $\mathrm{E}$, Rizzari $\mathrm{C}$, et al.Adrenal axis function after high-dose steroid therapy for childhood acute lymphoblastic leukemia. Pediatric Blood \& Cancer 2008;50(3):537-41.

Felner 2000 \{published data only (unpublished sought but not used)\} Felner EI, Thompsom MT, Ratliff AF, White PC, Dickson BA. Time course of recovery of adrenal function in children treated for leukemia. The Journal of Pediatrics 2000;137(1): $21-4$.

Kuperman 2001 \{published data only (unpublished sought but not used)\}

Kuperman H, Damiani D, Chrousos GP, Dichtchekenian V, Manna TD, Filho VO, et al.Evaluation of the hypothalamicpituitary-adrenal axis in children with leukemia before and after 6 weeks of high-dose glucocorticoid therapy. The Journal of Clinical Endocrinology \& Metabolism 2001;86(7): 2993-6.

Mahachoklertwattana 2004 \{published and unpublished data\} Mahachoklertwattana P, Vilaiyuk S, Hongeng S, Okascharoen C. Suppression of adrenal function in children with acute lymphoblastic leukemia following induction therapy with corticosteroid and other cytotoxic agents. The Journal of Pediatrics 2004;144(6):736-40.
Petersen 2003 \{published and unpublished data\}

Petersen KB, Müller J, Rasmussen M, Schmiegelow K. Impaired adrenal function after glucocorticoid therapy in children with acute lymphoblastic leukemia. Medical and Pediatric Oncology 2003;41(2):110-4.

Rix 2005 \{published and unpublished data\}

Rix M, Birkebaek NH, Rosthøj S, Clausen N. Clinical impact of corticosteroid-induced adrenal suppression during treatment for acute lymphoblastic leukemia in children: a prospective observational study using the lowdose adrenocorticotropin test. The Journal of Pediatrics 2005;147(5):645-50.

\section{References to studies excluded from this review}

Bessho 1984 \{published data only\} Bessho F, Kagawa J, Mizutani S, Egi S, Fujiu M, Kaku $\mathrm{H}$, et al.Effects of antileukemic therapy of endocrine functions and development of children. European Paediatric Haematology and Oncology 1984;1:135-41.

Birkebaek 1998 \{published data only (unpublished sought but not used)\}

Birkebaek NH, Fisker S, Clausen N, Tuovinen V, SindetPedersen S, Christiansen JS. Growth and endocrinological disorders up to 21 years after treatment for acute lymphoblastic leukemia in childhood. Medical and Pediatric Oncology 1998;30(6):351-6.

Felder-Puig 2007 \{published data only\} Felder-Puig R, Scherzer C, Baumgartner M, Ortner M, Aschenbrenner C, Bieglmayer C, et al.Glucocorticoids in the treatment of children with acute lymphoblastic 
leukemia and Hodgkin's disease: a pilot study on the adverse psychological reactions and possible associations with neurobiological, endocrine, and genetic markers. Clinical Cancer Research 2007;13(23):7093-100.

Lightner 1981 \{published data only\}

Lightner ES, Johnson H, Corrigan JJ Jr. Rapid adrenocortical recovery after short-term glucocorticoid therapy. American Journal of Diseases of Children 1981;135 (9):790-2.

Pawlaczyk 1993 \{published data only\}

Pawlaczyk B, Malecka EH, Krause W. Adrenocortical function and reserve in children treated for acute lymphoblastic leukaemia [Czynnosc i rezerwa korowonadnerczowa u dzieci po leczeniu ostrej bialaczki limfoblastycznej]. Pediatria Polska 1993;68:49-54.

Silva 2006 \{published data only\}

Silva IN, Cunha CF, Finch FL, Colosimo EA. Evaluation of hypothalamic-pituitary-adrenal axis recovery after corticotherapy by using basal cortisol secretion [Avaliação da recuperação do eixo hipotalâmicohipofisário-adrenal após corticoterapia por meio do cortisol basal]. Arquivos Brasileiros de Endocrinologia e Metabologia 2006;50(1): $118-24$.

\section{Additional references}

\section{Abdu 1999}

Abdu TA, Elhadd TA, Neary R, Clayton RN. Comparison of the low dose short synacthen test $(1 \mathrm{microg})$, the conventional dose short synacthen test (250 microg), and the insulin tolerance test for assessment of the hypothalamopituitary-adrenal axis in patients with pituitary disease. The Journal of Clinical Endocrinology and Metabolism 1999;84 (3):838-43.

Agwu 1999

Agwu JC, Spoudeas H, Hindmarsh PC, Pringle PJ, Brook CG. Tests of adrenal insufficiency. Archives of Disease in Childhood 1999;80:330-33.

\section{Albert 2001}

Albert SG, DeLeon MJ, Silverberg AB. Possible association between high-dose fluconazole and adrenal insufficiency in critically ill patients. Critical Care Medicine 2001;29(3): 668-70.

\section{Biostat, Inc, USA}

Borenstein M, Rothstein H. Comprehensive Meta Analysis. New Jersey, USA: Biostat, Inc, 1999.

\section{Böttner 2005}

Böttner A, Kratzsch J, Liebermann S, Keller A, Pfaffle RW, Kiess W, et al.Comparison of adrenal function tests in children - the glucagon stimulation test allows the simultaneous assessment of adrenal function and growth hormone response in children. Journal of Pediatric Endocrinology \& Metabolism 2005;18(5):433-42.

Christensen 2005

Christensen MS, Heyman M, Möttönen M, Zeller B, Jonmundsson G, Hasle H. Treatment-related death in childhood acute lymphoblastic leukaemia in the Nordic countries: 1992-2001. British Journal of Haematology 2005; 131(1):50-8.

DCOG 2008

DCOG. 2008.

\section{Dickstein 1997}

Dickstein G, Spigel D, Arad E, Shechner C. One microgram is the lowest ACTH dose to cause a maximal cortisol response. There is no diurnal variation of cortisol response to submaximal ACTH stimulation. European Journal of Endocrinology 1997;137(2):172-5.

Grimes 2002

Grimes DA, Schulz KF. Cohort studies: marching towards outcomes. Lancet 2002;359(9303):341-5.

\section{Henzen 2000}

Henzen C, Suter A, Lerch E, Urbinelli R, Schorno XH, Briner VA. Suppression and recovery of adrenal response after short-term, high-dose glucocorticoid treatment. Lancet 2000;85(2):542-5.

\section{Hettmannsperger 1992}

Hettmannsperger U, Detmar M, Owskianowski M, Tenorio S, Kammler HJ, Orfanos CE. Cytokine-stimulated human dermal microvascular endothelial cells produce interleukin 6 - inhibition by hydrocortisone, dexamethasone, and calcitriol. The Journal of Investigative Dermatology 1992;99 (5):531-6.

Higgins 2009

Higgins JPT, Green S (editors). Cochrane Handbook for Systematic Reviews of Interventions Version 5.0.2. [updated September 2009]. The Cochrane Collaboration, 2009. Available from www.cochrane-handbook.org.

Hurwitz 2000

Hurwitz CA, Silverman LB, Schorin MA, Clavell LA, Dalton VK, Glick KM, et al.Substituting dexamethasone for prednisone complicates remission induction in children with acute lymphoblastic leukemia. Cancer 2000;88(8): 1964-9.

\section{Igarashi 2005}

Igarashi S, Manabe A, Ohara A, Kumagai M, Saito T, Okimoto $\mathrm{Y}$, et al.No advantage of dexamethasone over prednisolone for the outcome of standard-and intermediaterisk childhood acute lymphoblastic leukemia in the Tokyo Children's Cancer Study Group L95-14 protocol. American Journal of Clinical Oncology 2005;23(27):6489-98.

\section{Krasner 1999}

Krasner AS. Glucocorticoid-induced adrenal insufficiency. JAMA 1999;282(7):671-6.

\section{Laupacis 1994}

Laupacis A, Wells G, Richardson WS, Tugwell P. Users' guides to the medical literature. V. How to use an article about prognosis. Evidence-Based Medicine Working Group. JAMA 1994;272(3):234-7.

\section{Maghnie 2005}

Maghnie M, Uga E, Temporini F, Di lorgi N, Secco A, Tinelli $\mathrm{C}$, et al.Evaluation of adrenal function in patients with growth hormone deficiency and hypothalamic-

Hypothalamic-pituitary-adrenal (HPA) axis suppression after treatment with glucocorticoid therapy for childhood acute lymphoblastic 
pituitary disorders: comparison between insulin-induced hypoglycemia, low-dose ACTH and CRH stimulation tests. European Journal of Endocrinology 2005;152(5):735-41.

\section{Module CCG}

Kremer LCM, van Dalen EC, Moher D, Caron HN. Childhood Cancer Group. In: The Cochrane Library, 2010, Issue 12. Chichester. Wiley-Blackwell.

\section{Nyhlén 2000}

Nyhlén K, Linden M, Andersson R, Uppugunduri S. Corticosteroids and interferons inhibit cytokine-induced production of IL- 8 by human endothelial cells. Cytokine 2000;12(4):355-60.

\section{Planey 2000}

Planey SL, Litwack G. Glucocorticoid-induced apoptosis in lymphocytes. Biochemical and Biophysical Research Communications 2000;279(2):307-12.

\section{Pruckner 2009}

Pruckner C, Attarbaschi A, Peters C, Dworzak MN, Pötschger U, Urban C, et al.Induction death and treatmentrelated mortality in first remission of children with acute lymphoblastic leukemia: a population-based analysis of the Austrian Berlin-Frankfurt-Münster study group. Leukemia: Official Journal of the Leukemia Society of America, Leukemia Research Fund, UK 2009;23(7):1264-9.

\section{Rao 1987}

Rao RH, Spathis GS. Intramuscular glucagon as a provocative stimulus for the assessment of pituitary function: growth hormone and cortisol responses. Metabolism 1987; 36(7):658-63.

\section{Rubnitz 2004}

Rubnitz JE, Lensing S, Zhou Y, Sandlund JT, Razzouk BI, Ribeiro RC. Death during induction therapy and first remission of acute leukemia in childhood: the St. Jude experience. Cancer 2004;101(7):1677-84.

\section{Schlaghecke 1992}

Schlaghecke R, Kornely E, Santen RT, Ridderskamp P. The effect of long-term glucocorticoid therapy on pituitaryadrenal responses to exogenous corticotropin-releasing hormone. The New England Journal of Medicine 1992;326 (4):226-30.

\section{Shah 1992}

Shah A, Stanhope R, Matthew D. Hazards of pharmacological tests of growth hormone secretion in childhood. British Medical Journal 1992;304(6820):173-4.

\section{Shibata 2001}

Shibata S, Kami M, Kanda Y, Machida U, Iwata H, Kishi Y, et al.Acute adrenal failure associated with fluconazole after administration of high-dose cyclophosphamide. American Journal of Hematology 2001;66(4):303-5.

Shulman 2007

Shulman DI, Palmert MR, Kemp SF, Lawson Wilkins Drug and Therapeutics Committee. Adrenal insufficiency: still a cause of morbidity and death in childhood. Pediatrics 2007; 119(2):484-94.

Te Poele 2007

Te Poele EM, de Bont ES, Marike Boezen H, Revesz T, Bökkerink JP, Bieshuizen A, et al.Dexamethasone in the maintenance phase of acute lymphoblastic leukaemia treatment: is the risk of lethal infections too high?. European Journal of Cancer 2007;43(17):2532-6.

\section{Tjordman 2000}

Tordjman K, Jaffe A, Trostanetsky Y, Greenman Y, Limor R, Stern N. Low-dose (1 microgram) adrenocorticotrophin (ACTH) stimulation as a screening test for impaired hypothalamo-pituitary-adrenal axis function: sensitivity, specificity and accuracy in comparison with the high-dose (250 microgram) test. Clinical Endocrinology 2000;52(5): 633-40.

\section{Van Tijn 2008}

Van Tijn DA, De Vijlder JJ, Vulsma T. Role of corticotropinreleasing hormone testing in assessment of hypothalamicpituitary-adrenal axis function in infants with congenital central hypothyroidism. Journal of Clinical Endocrinology \& Metabolism 2008;93(10):3794-803.

\section{Vanderschueren-Lodeweyckx 1974}

Vanderschueren-Lodeweyckx M, Wolter R, Malvaux P, Eggermont E, Eeckels R. The glucagon stimulation test: effect of plasma growth hormone and on immunoreactive insulin, cortisol, and glucose in children. The Journal of Pediatrics 1974;85(2):182-7.

\section{Waage 1988}

Waage A, Bakke O. Glucocorticoids suppress the production of tumour necrosis factor by lipopolysaccharide-stimulated human monocytes. Immunology 1988;63(2):299-302.

\section{Wheeler 1996}

Wheeler K, Chessells JM, Bailey CC, Richards SM. Treatment related deaths during induction and in first remission in acute lymphoblastic leukaemia: MRC UKALL X. Archives of Disease in Childhood 1996;74(2):101-7. [DOI: 10.1136/adc.74.2.101]

* Indicates the major publication for the study 


\section{CHARACTERISTICS OFSTUDIES}

\section{Characteristics of included studies [ordered by study ID]}

\section{Cunha 2004}

\begin{tabular}{|c|c|}
\hline Methods & $\begin{array}{l}\text { Study type: prospective multicentre study } \\
\text { Setting: Brazil (University Hospital of Federal University of Minas Gerais, Santa Casa de Misericórdia and Hospital } \\
\text { Felício Rocho, Belo Horizonte). This information was based on additional information provided by the authors }\end{array}$ \\
\hline Participants & $\begin{array}{l}35 \text { children (median age at diagnosis/first HPA axis function test } 6.9 \text { years (range } 1.2 \text { to } 14.4 \text { years); } 17 \text { boys and } 18 \\
\text { girls) with ALL }\end{array}$ \\
\hline Interventions & $\begin{array}{l}\text { Treatment according to the Brazilian Group for Treatment of ALL, } 1993 \text { protocol (GBTLI-93). Specific medication } \\
\text { not defined } \\
\text { Type of glucocorticoid therapy: dexamethasone }\left(6 \mathrm{mg} / \mathrm{m}^{2} / \text { day, twice daily) given for } 28 \text { days }\right. \\
\text { Cumulative dexamethasone dose } 183.75 \mathrm{mg} / \mathrm{m}^{2} \\
\text { Duration of glucocorticoid therapy: } 28 \text { days }+9 \text { days' tapering doses (in total } 37 \text { days) } \\
\text { Methods of cessation of glucocorticoid therapy: dose reduction over } 10 \text { days ( } 50 \% \text { each } 3 \text { days, with complete } \\
\text { withdrawal on the } 10 \text { th day) } \\
\text { No control intervention }\end{array}$ \\
\hline Outcomes & $\begin{array}{l}\text { Specific HPA axis function test: the ovine CRH stimulus test at } 8 \text { a.m. (after an overnight fasting period), including } \\
\text { cortisol basal morning value } \\
\text { Moment of testing: before introduction of dexamethasone, on the } 8 \text { th day and the } 28 \text { th day of dexamethasone use, } \\
\text { and } 48 \text { hours and } 1 \text { month after cessation of dexamethasone. The tests were performed during treatment for ALL } \\
\text { Cut-off limits defined by original studies: baseline cortisol: } 5 \text { to } 25 \mu \mathrm{g} / \mathrm{dL}(138.9 \text { to } 694.4 \mathrm{nmol} / \mathrm{L} \text { ) and stimulated } \\
\text { cortisol levels were compared with the levels before treatment }\end{array}$ \\
\hline Notes & $\begin{array}{l}7 \text { patients were lost to follow-up at the } 8 \text { th and } 28 \text { th test day, } 1 \text { more } 48 \text { hours after glucocorticoid therapy test and } \\
7 \text { more } 1 \text { month after glucocorticoid therapy test } \\
\text { Length of follow-up after glucocorticoid therapy: } 1 \text { month } \\
\text { Risk factors were not evaluated }\end{array}$ \\
\hline
\end{tabular}

\section{Einaudi 2008}

Methods Study type: multicentre RCTSetting: Department of Pediatric Onco-Hematology, University of Turin, Italy and Department of Pediatrics, University of Milano-Bicocca, Hospital of Monza, Italy. This information was based on additional information provided by the authors

Participants 64 children (24 patients that received dexamethasone: mean age at diagnosis 4 years 11 months (range 1 year 2 months to 12 years 1 month), 11 boys and 13 girls; 40 patients that received prednisone: mean age at diagnosis 6 years 9 months (range 1 year 2 months to 17 years 6 months), 18 boys and 22 females) with ALL. This information was based on additional information provided by the authors

Interventions Treatment according to the AIEOP ALL 2000 study. Induction phase IA: prednisone (from day 8 randomisation prednisone or dexamethasone), vincristine, daunorubicin, Escherichia coli L-asparaginase and intrathecal methotrexate. Induction phase IB: 6-mercaptopurine, cyclophosphamide, cytosine-arabinoside and intrathecal methotrexate Type of glucocorticoid therapy: induction phase: oral prednisone $\left(60 \mathrm{mg} / \mathrm{m}^{2} /\right.$ day, divided into 3 daily doses $)$ given on days 1 to 7 . On day 8 the children were randomised to receive either dexamethasone $\left(10 \mathrm{mg} / \mathrm{m}^{2} /\right.$ day $)$ or prednisone

Hypothalamic-pituitary-adrenal (HPA) axis suppression after treatment with glucocorticoid therapy for childhood acute lymphoblastic 


\section{Einaudi 2008 (Continued)}

$\left(60 \mathrm{mg} / \mathrm{m}^{2} /\right.$ day) both divided into 3 oral doses until day 29. From day 30 onwards, the dose of both corticosteroids was tapered by $50 \%$ every 3 days, until complete withdrawal over 9 days

Cumulative dose of glucocorticoid therapy: prednisone $420 \mathrm{mg} / \mathrm{m}^{2}+$ dexamethasone $246.25 \mathrm{mg} / \mathrm{m}^{2}$ or prednisone $1477.50 \mathrm{mg} / \mathrm{m}^{2}$

Duration of glucocorticoid therapy: prednisone 7 days + dexamethasone 22 days or prednisone 22 days +9 days' tapering doses (in total 39 days)

Methods of cessation of glucocorticoid therapy: dose was tapered by $50 \%$ every 3 days, until complete withdrawal over 9 days

Outcomes Specific HPA axis function test: basal cortisol between 8 and 9 a.m. at diagnosis and the low-dose ACTH test between 8 and 11 a.m. ( $1 \mu \mathrm{g} / 1.74 \mathrm{~m}^{2}$ of tetracosactrin (Synacthen, Novartis, Basal, Switzerland), basal morning value cortisol, after 30 and 60 minutes)

Moment of testing: at diagnosis basal cortisol was determined. The first low-dose ACTH stimulation test was performed 24 hours after the last tapering dose of glucocorticoid (on day 39), which was given as a single dose in the morning. The tests were performed during treatment for ALL

Cut-off limits defined by original studies: basal cortisol: 6 to $30 \mu \mathrm{g} / \mathrm{dL}$ (167 to $833 \mathrm{nmol} / \mathrm{L})$. Low-dose ACTH test: normal response $\geq 18 \mu \mathrm{g} / \mathrm{dL}(\geq 500 \mathrm{nmol} / \mathrm{L})$

Notes $\quad 0$ patients were lost to follow-up

Length of follow-up after glucocorticoid therapy: patients with suppressed levels underwent further low-dose ACTH tests between 7 and 14 days from the last glucocorticoid dose and every 2 weeks thereafter until cortisol levels normalised. The total follow-up duration was 10 weeks

Risk factors were not evaluated

Felner 2000

Methods Study type: prospective single-centre study

Setting: Children's Medical Center of Dallas (University of Texas Southwestern Medical School). This information was based on additional information provided by the authors

Participants 10 children (mean age at diagnosis $5.3 \pm 2.9$ years (range 2.0 to 9.9 years); 7 boys and 3 girls) with early B-cell lineage ALL

Interventions Induction therapy: dexamethasone, vincristine, L-asparaginase and daunorubicin. High-risk therapy: 1 additional lumbar puncture with intrathecal chemotherapy during induction

Type of glucocorticoid therapy: induction phase: oral dexamethasone $\left(6 \mathrm{mg} / \mathrm{m}^{2} /\right.$ day, divided into 2 daily doses $)$ for 28 consecutive days

Cumulative dexamethasone dose $168 \mathrm{mg} / \mathrm{m}^{2}$

Duration of glucocorticoid therapy: 28 days

Methods of cessation of glucocorticoid therapy: abrupt

No control intervention

Outcomes Specific HPA axis function test: $250 \mu \mathrm{g}$ cosyntropin stimulation test (synthetic corticotrophin 1-24/ ACTH test) iv between 8 and 10 a.m. (Cotrosyn, Organon) (basal morning value cortisol and after 45 minutes)

Moment of testing: at diagnosis (baseline), 24 hours after completion of the dexamethasone course and every 4 weeks thereafter until normalisation of adrenal function. The tests were performed during treatment for ALL

Cut-off limits defined by original studies: baseline cortisol: not defined. Low-dose ACTH test: normal response $\geq$ $18 \mu \mathrm{g}(\geq 500 \mathrm{nmol} / \mathrm{L})$

Hypothalamic-pituitary-adrenal (HPA) axis suppression after treatment with glucocorticoid therapy for childhood acute lymphoblastic 


\section{Felner 2000 (Continued)}

Notes patients were lost to follow-up
Length of follow-up after glucocorticoid therapy: patients with suppressed levels underwent further tests every 4
weeks thereafter until cortisol levels normalised. The total follow up duration was 8 weeks
Risk factors were not evaluated

\section{Kuperman 2001}

Methods Study type: prospective single-centre study

Setting: The Oncology Department of the Children's Institute, Hospital das Clinicas-Sao Paulo University School of Medicine, Brazil

Participants 15 children (age at diagnosis 5 months to 12 years; 5 boys and 10 girls) with ALL

Interventions Dexamethasone, daunomycin, vincristine, L-asparaginase and cytosine-arabinoside

Type of glucocorticoid therapy: induction phase: oral dexamethasone $\left(6 \mathrm{mg} / \mathrm{m}^{2} /\right.$ day, divided into 3 daily doses $)$ for 42 consecutive days

Cumulative dexamethasone dose $252 \mathrm{mg} / \mathrm{m}^{2}$

Duration of glucocorticoid therapy: 42 days

Methods of cessation of glucocorticoid therapy: abrupt

No control intervention

Outcomes Specific HPA axis function test: $1 \mu \mathrm{g} / \mathrm{kg}$ ovine CRH stimulation test iv, after an 8-hours fast, between 8 and 9 a.m. (basal morning value cortisol and after 15, 30, 60 and 90 minutes)

Moment of testing: before dexamethasone therapy (baseline), 7 and 14 days after the last dose of dexamethasone. It was not defined if tests were performed during treatment for ALL

Cut-off limits defined by original studies: basal cortisol: $7.0 \mu \mathrm{g} / \mathrm{dL}$. This information was based on additional information provided by the authors. Ovine CRH test: cortisol above $12.8 \mu \mathrm{g} / \mathrm{dL}(353.2 \mathrm{nmol} / \mathrm{L})$ was considered normal (basal and peak cortisol levels of the 3 different time points were compared with each other)

Notes Based on additional information provided by the authors, 1 patient was lost to follow-up 14 days after administration of dexamethasone

Length of follow-up after glucocorticoid therapy: 14 days

Risk factors were not evaluated

\section{Mahachoklertwattana 2004}

Methods Study type: prospective single-centre study

Setting: Department of Pediatrics, Faculty of Medicine, Ramathibodi Hospital, Bangkok, Thailand

Participants 24 children (median age at diagnosis 3.5 years (range 1 to 14 years); 13 boys and 11 girls) with newly diagnosed ALL

Interventions According to the modification of St Jude Children's Research Hospital Total XIII Protocol for ALL. Standard induction therapy: prednisolone, vincristine, L-asparaginase, doxorubicin, etoposide and cytosine-arabinoside

Type of glucocorticoid therapy: induction phase: oral prednisolone $\left(40 \mathrm{mg} / \mathrm{m}^{2} /\right.$ day, divided into 3 daily doses) for 28 consecutive days. 4 weeks after completion of the induction therapy, the patients received maintenance therapy consisting of a 7-day course of high-dose dexamethasone $8 \mathrm{mg} / \mathrm{m}^{2} /$ day, every 4 weeks in conjunction with other chemotherapeutic agents according to the risk classification 
Cumulative prednisolone dose $1120 \mathrm{mg} / \mathrm{m}^{2}$. Cumulative dose of dexamethasone per patient depended on how long the patient was followed up. A dexamethasone course $\left(56 \mathrm{mg} / \mathrm{m}^{2} /\right.$ day $)$ was administrated at 4, 8, 12 and 16 weeks after induction therapy. The maximum cumulative dose of dexamethasone ( 4 courses) is $224 \mathrm{mg} / \mathrm{m}^{2}$

Duration of glucocorticoid therapy: 28 days of prednisolone and additional 7-day course of dexamethasone

Methods of cessation of glucocorticoid therapy: abrupt

No control intervention

Outcomes Specific HPA axis function test: serum cortisol level at 8 a.m., at diagnosis (baseline) and low-dose ACTH stimulation test $(1 \mu \mathrm{g}$ cosyntropin, Cotrosyn, Organon, West Orange, NJ) at 8 a.m. after an overnight fast (basal cortisol and after 30 minutes)

Moment of testing: baseline adrenal function was assessed by determination of serum cortisol level at 8 a.m. before induction therapy. The first low-dose ACTH stimulation test was performed 2 weeks after discontinuation of prednisolone. Patients with adrenal insufficiency underwent repeated ACTH tests 4 weeks after completion of the prednisolone course and every 4 weeks thereafter in the morning of the day in which the patients were admitted for the next course of maintenance chemotherapy until normalisation. The tests were performed during treatment for ALL

Cut-off limits defined by original studies: basal cortisol: not defined. Low-dose ACTH test: normal response $\geq 18$ $\mu \mathrm{g} / \mathrm{dL}(\geq 500 \mathrm{nmol} / \mathrm{L})$

Notes $\quad 0$ patients were lost to follow-up

Length of follow-up after glucocorticoid therapy: up to 20 weeks

Risk factors were not evaluated

Petersen 2003

Methods Study type: prospective single-centre study

Setting: The University Hospital, Rigshospitalet, Copenhagen, Denmark

Participants 17 children (median age at diagnosis 5.4 years (range 2 to 15 years)) with ALL

Interventions According to the risk group by the NOPHO ALL-1992 or ALL-2000 protocol. 10 patients were studied after receiving prednisolone, weekly vincristine, 4 doses of intrathecal methotrexate, L-asparaginase and doxorubicin. 7 additional patients were studied following re-induction therapy with dexamethasone, weekly vincristine and daunorubicin, 4 doses of L-asparaginase and intrathecal methotrexate

Type of glucocorticoid therapy: induction phase $(\mathrm{n}=10)$ : prednisolone $\left(60 \mathrm{mg} / \mathrm{m}^{2} /\right.$ day, in 3 daily doses $)$ during the first 5 weeks of induction therapy followed by 9 days of tapering. 1 -week courses of prednisolone $\left(60 \mathrm{mg} / \mathrm{m}^{2} /\right.$ day, based on additional information provided by the authors) were administered every 4 to 10 weeks as part of the reinduction therapy, beginning approximately 8 weeks after prednisolone

Re-induction therapy $(\mathrm{n}=7)$ : dexamethasone $\left(10 \mathrm{mg} / \mathrm{m}^{2} /\right.$ day, divided in 3 daily doses $)$ for 3 weeks on protocol days 169 to 190 (4 intermediate-risk patients) or days 246 to 267 ( 3 high-risk patients) followed by 9 days of tapering. The high-risk patients received two 1 -week courses of prednisolone $\left(40 \mathrm{mg} / \mathrm{m}^{2} /\right.$ day $) 4$ and 8 weeks prior to the dexamethasone therapy. 1 -week courses of prednisolone $\left(60 \mathrm{mg} / \mathrm{m}^{2} /\right.$ day $)$ were administered every 4 to 10 weeks as part of the re-induction therapy, beginning approximately 11 weeks after dexamethasone therapy

Cumulative dose: induction therapy: $2100 \mathrm{mg} / \mathrm{m}^{2}+157.5 \mathrm{mg} / \mathrm{m}^{2}$ prednisolone. 1 patient received additional 840 $\mathrm{mg} / \mathrm{m}^{2}$ prednisolone during the period of adrenal insufficiency. Re-induction therapy: $210 \mathrm{mg} / \mathrm{m}^{2}+26.5 \mathrm{mg} / \mathrm{m}^{2}$ dexamethasone. High-risk patients received $560 \mathrm{mg} / \mathrm{m}^{2}$ prednisolone in advance 1 patient received an additional $420 \mathrm{mg} / \mathrm{m}^{2}$ prednisolone during the period of adrenal insufficiency and 2 patients received an additional $1260 \mathrm{mg} /$ $\mathrm{m}^{2}$ prednisolone during the period of adrenal insufficiency

Hypothalamic-pituitary-adrenal (HPA) axis suppression after treatment with glucocorticoid therapy for childhood acute lymphoblastic 
Duration of glucocorticoid therapy: induction therapy: 35 days of prednisolone +9 days' tapering doses. 1 patient received an additional 14 days of prednisolone. Re-induction therapy: 21 days of dexamethasone + 9 days' tapering doses. The high-risk patients received 14 days of prednisolone 4 and 8 weeks prior to dexamethasone therapy. After the dexamethasone course, the high-risk patients also received prednisolone for 1 week $(n=1)$ or 3 weeks $(n=2)$

Methods of cessation of glucocorticoid therapy: $50 \%$ each 3 days, over 9 days in total

No control intervention

Outcomes Specific HPA axis function test: ACTH stimulation test $(250 \mu \mathrm{g}$ tetracosactide (Synacthen, Novartis) between 8 and 11 a.m. (basal cortisol and after 30 and 60 minutes)

Moment of testing: the adrenal function was assessed by an ACTH stimulation test within 2 weeks after discontinuation of glucocorticoid therapy. The test was repeated every 3 to 5 weeks until recovery or end of follow-up. The tests were performed during treatment for ALL

Cut-off limits defined by original studies: low-dose ACTH test: normal response $>500 \mathrm{nmol} / \mathrm{L}$

Notes $\quad$ No patients were lost to follow-up

Length of follow-up after glucocorticoid therapy: fluctuating

Fluconazole therapy as a risk factor for adrenal insufficiency was evaluated

Rix 2005

Methods Study type: prospective multicentre study

Setting: Department of pediatrics, Aalborg University Hospital and the department of pediatrics, Aarhus University Hospital Skejby. This information was based on additional information provided by the authors

Participants 24 children (median age at diagnosis 4.5 years (range 1.8 to 14.6 years); 17 boys and 7 girls) with newly diagnosed ALL. 12 had standard-risk ALL according to the Nordic risk criteria, 7 had intermediate risk and 5 had high risk

Interventions According to the NOPHO ALL-92 protocol

Type of glucocorticoid therapy: all children received prednisolone $\left(60 \mathrm{mg} / \mathrm{m}^{2} /\right.$ day, in 3 daily doses $)$ during the first 5 weeks of induction therapy followed by 9 days of tapering. All children received 1 -week courses of prednisolone $\left(60 \mathrm{mg} / \mathrm{m}^{2} /\right.$ day $)$ without tapering, and children with intermediate-risk and high-risk criteria received an additional 3 -week course of dexamethasone $\left(10 \mathrm{mg} / \mathrm{m}^{2} /\right.$ day $)$ with tapering over a 9-day period

Cumulative dose of glucocorticoid therapy: all patients received $2100 \mathrm{mg} / \mathrm{m}^{2}+157.5 \mathrm{mg} / \mathrm{m}^{2}$ prednisolone. In addition, several courses (not defined) of $420 \mathrm{mg} / \mathrm{m}^{2} /$ day prednisolone. Intermediate-risk and high-risk patients: additional $210 \mathrm{mg} / \mathrm{m}^{2}+26.25 \mathrm{mg} / \mathrm{m}^{2}$ dexamethasone

Duration of glucocorticoid therapy: induction therapy: 35 days of prednisolone +9 days' tapering doses. Additional 7-day courses of prednisolone. Intermediate-risk and high-risk patients: additional 21 days dexamethasone +9 days tapering doses

Methods of cessation of glucocorticoid therapy: $50 \%$ every 3 days over 9 days in total

No control intervention

Outcomes Specific HPA axis function test: low-dose ACTH stimulation test ( $1 \mu \mathrm{g}$ tetracosactide (Synacthen, Novartis) between 8 and 10 a.m. (basal cortisol and after 30 minutes)

Moment of testing: for each child: before the 5-week course of prednisolone (weeks 1 to 5) and days 1, 3 and 5 after tapering was completed. Before the 1-week course of prednisolone (weeks 14 (standard risk), 28 (high risk) or 37 (intermediate risk)) and on day 2 after cessation. Before the 3-week course of dexamethasone (weeks 25 to 27 (intermediate risk) or 36 or 38 (high risk)), before tapering, and on days 1, 3 and 7 after tapering was completed. The tests were performed during treatment for ALL

Cut-off limits defined by original studies: low-dose ACTH test: normal response $>500 \mathrm{nmol} / \mathrm{L}$

Hypothalamic-pituitary-adrenal (HPA) axis suppression after treatment with glucocorticoid therapy for childhood acute lymphoblastic 
Notes Based on additional information provided by the authors, 5 patients were lost to follow-up Length of follow-up after glucocorticoid therapy: varied

Risk factors were not evaluated

ACTH: adrenocorticotropic hormone

AIEOP: Associazione Italiana Ematologia e Oncologia

ALL: acute lymphoblastic leukaemia

CRH: corticotrophin-releasing hormone

HPA: hypothalamic-pituitary-adrenal

iv: intravenous

NOPHO: Nordic Society of Pediatric Hematology and Oncology

RCT: randomised controlled trial

\section{Characteristics of excluded studies [ordered by study ID]}

\begin{tabular}{ll}
\hline Study & Reason for exclusion \\
\hline Bessho 1984 & HPA axis was not examined \\
\hline Birkebaek 1998 & $\begin{array}{l}\text { No data on intervention (doses, duration, methods of cessation of glucocorticoid therapy) } \\
\text { No data on cut-off limits of HPA axis function tests } \\
\text { No accurate data on follow-up period } \\
\text { Data on patients without cranial irradiation were not reported separately }\end{array}$ \\
\hline Felder-Puig 2007 & HPA axis function was only examined during glucocorticoid treatment \\
\hline Lightner 1981 & Patients received cranial irradiation \\
\hline Pawlaczyk 1993 & Patients received cranial irradiation \\
\hline Silva 2006 & Double publication of Cunha 2004 \\
\hline
\end{tabular}

HPA: hypothalamic-pituitary-adrenal 


\section{DATA ANDANALYSES}

This review has no analyses.

\section{ADDITIONAL TABLES}

Table 1. Risk of bias assessment criteria for observational studies

\begin{tabular}{|c|c|c|}
\hline & Internal validity & External validity \\
\hline Study group & $\begin{array}{l}\text { Selection bias (representative: yes/no): } \\
\text { - if it consisted of more than } 90 \% \text { of the original } \\
\text { cohort of ALL patients treated with glucocorticoids } \\
\text { - or if it was a random sample with respect to the } \\
\text { treatment }\end{array}$ & $\begin{array}{l}\text { Reporting bias (well defined: yes/no): } \\
\text { - if the treatment protocol was mentioned } \\
\text { - and if the (cumulative) dose of glucocorticoid } \\
\text { treatment was mentioned } \\
\text { - and if the type of glucocorticoid treatment was } \\
\text { mentioned } \\
\text { - and if the duration of glucocorticoid treatment } \\
\text { was mentioned } \\
\text { - and if the method of cessation of glucocorticoid } \\
\text { treatment was mentioned }\end{array}$ \\
\hline Follow-up & $\begin{array}{l}\text { Attrition bias (adequate: yes/no): } \\
\text { - if the outcome was assessed at the end date of the } \\
\text { study for } 60 \% \text { to } 90 \% \text { of the study group } \\
\text { - or if the outcome was assessed for more than } 90 \% \\
\text { of the study group but with an unknown end date }\end{array}$ & $\begin{array}{l}\text { Reporting bias (well-defined: yes/no): } \\
\text { - if the length of follow-up was mentioned } \\
\text { - and if the frequency of measuring the outcomes } \\
\text { was mentioned }\end{array}$ \\
\hline Outcome & $\begin{array}{l}\text { Detection bias (blinding: yes/no): } \\
\text { - if the outcome assessor was blinded to } \\
\text { glucocorticoid treatment }\end{array}$ & $\begin{array}{l}\text { Reporting bias (well-defined: yes/no): } \\
\text { - if the methods of detection were described } \\
\text { - if the outcome definition was objective and } \\
\text { precise }\end{array}$ \\
\hline Risk estimation & $\begin{array}{l}\text { Confounding (adjustment for other factors: yes/no): } \\
\text { - if important prognostic factors (i.e. age, sex, co- } \\
\text { treatment) or follow-up were taken adequately into } \\
\text { account }\end{array}$ & $\begin{array}{l}\text { Analysis (well-defined: yes/no): } \\
\text { - if a relative risk, odds ratio, attributable risk, } \\
\text { linear or logistic regression model, mean difference, or } \\
\mathrm{Chi}^{2} \text { statistic was calculated }\end{array}$ \\
\hline
\end{tabular}

Table 2. Risk of bias assessment criteria for randomised controlled trials

\section{Selection bias}

Sequence generation (adequate: yes/no):

- if the rule for allocating interventions to participants was based on some chance (random) process

Allocation concealment (adequate: yes/no):

- if the randomisation method did not allow investigator and participant to know or influence the allocation of treatment before eligible participants entered the study

\section{/ Performance bias}

Blinding of care providers (yes/no):

- if knowledge of the allocated intervention was adequately prevented during the study

Blinding of participants (yes/no)

Hypothalamic-pituitary-adrenal (HPA) axis suppression after treatment with glucocorticoid therapy for childhood acute lymphoblastic 
Table 2. Risk of bias assessment criteria for randomised controlled trials (Continued)

- if knowledge of the allocated intervention was adequately prevented during the study

\section{Detection bias}

Blinding of outcome assessors (yes/no; assessed for each outcome separately):

- if knowledge of the allocated intervention was adequately prevented during the study

\section{Attrition bias}

Incomplete outcome data (adequate: yes/no; assessed for each outcome separately):

- if incomplete outcome (attrition and exclusions) data have been adequately addressed

\section{Reporting bias}

Selective outcome reporting (yes/no):

- if the reports of the study were free of suggestion of selective outcome reporting

\section{Other bias}

Other bias (yes/no):

- if the study was free of other problems (i.e. potential source of bias related to the specific study design, premature termination of the study due to some data-dependent process, extreme baseline imbalance) that could put it at a high risk of bias

Table 3. Risk of bias in included observational studies

\begin{tabular}{|c|c|c|c|c|c|c|c|c|}
\hline Study & $\begin{array}{l}\text { Represen- } \\
\text { tative study } \\
\text { group }\end{array}$ & $\begin{array}{l}\text { Complete } \\
\text { follow-up } \\
\text { assessment }\end{array}$ & $\begin{array}{l}\text { Blinded } \\
\text { outcome as- } \\
\text { sessor }\end{array}$ & $\begin{array}{l}\text { Adjustment } \\
\text { important } \\
\text { con- } \\
\text { founders }\end{array}$ & $\begin{array}{l}\text { Well-de- } \\
\text { fined study } \\
\text { group }\end{array}$ & $\begin{array}{l}\text { Well- } \\
\text { defined fol- } \\
\text { low-up }\end{array}$ & $\begin{array}{l}\text { Well- } \\
\text { defined } \\
\text { outcome }\end{array}$ & $\begin{array}{l}\text { Well- } \\
\text { defined risk } \\
\text { estimation }\end{array}$ \\
\hline Cunha 2004 & $\begin{array}{l}\text { No, based } \\
\text { on addi- } \\
\text { tional infor- } \\
\text { mation pro- } \\
\text { vided by the } \\
\text { authors, the } \\
\text { described } \\
\text { study group } \\
\text { did not con- } \\
\text { sist of more } \\
\text { than } 90 \% \text { of } \\
\text { the original } \\
\text { cohort and } \\
\text { was no ran- } \\
\text { dom sample }\end{array}$ & $\begin{array}{l}\text { Yes, out- } \\
\text { come was as- } \\
\text { sessed for } \\
60 \% \text { to } 90 \% \\
\text { of the study } \\
\text { group at the } \\
\text { end date of } \\
\text { the study }\end{array}$ & $\begin{array}{l}\text { Unclear if } \\
\text { outcome as- } \\
\text { sessor } \\
\text { was blinded } \\
\text { to the gluco- } \\
\text { corticoid } \\
\text { treatment }\end{array}$ & $\begin{array}{l}\text { No, impor- } \\
\text { tant prog- } \\
\text { nostic fac- } \\
\text { tors or fol- } \\
\text { low-up were } \\
\text { not taken } \\
\text { into account }\end{array}$ & $\begin{array}{l}\text { Yes, treat- } \\
\text { ment proto- } \\
\text { col and (cu- } \\
\text { mu- } \\
\text { lative) dose, } \\
\text { type, dura- } \\
\text { tion } \\
\text { and form of } \\
\text { cessation } \\
\text { of glucocor- } \\
\text { ticoid treat- } \\
\text { ment were } \\
\text { mentioned }\end{array}$ & $\begin{array}{l}\text { Yes, } \\
\text { length of fol- } \\
\text { low-up and } \\
\text { frequency of } \\
\text { mea- } \\
\text { suring were } \\
\text { mentioned }\end{array}$ & $\begin{array}{l}\text { Yes, meth- } \\
\text { ods of de- } \\
\text { tection were } \\
\text { described } \\
\text { and out- } \\
\text { come defini- } \\
\text { tion was ob- } \\
\text { jective and } \\
\text { precise }\end{array}$ & $\begin{array}{l}\text { Yes, } \\
\text { mean differ- } \\
\text { ence was cal- } \\
\text { culated }\end{array}$ \\
\hline Felner 2000 & $\begin{array}{l}\text { Yes, based } \\
\text { on addi- } \\
\text { tional infor- } \\
\text { mation pro- } \\
\text { vided by the }\end{array}$ & $\begin{array}{l}\text { Yes, out- } \\
\text { come was as- } \\
\text { sessed for } \\
60 \% \text { to } 90 \% \\
\text { of the study }\end{array}$ & $\begin{array}{l}\text { Unclear if } \\
\text { outcome as- } \\
\text { sessor } \\
\text { was blinded } \\
\text { to the gluco- }\end{array}$ & $\begin{array}{l}\text { No, impor- } \\
\text { tant prog- } \\
\text { nostic fac- } \\
\text { tors or fol- } \\
\text { low-up were }\end{array}$ & $\begin{array}{l}\text { No, treat- } \\
\text { ment proto- } \\
\text { col was not } \\
\text { mentioned }\end{array}$ & $\begin{array}{l}\text { Yes, } \\
\text { length of fol- } \\
\text { low-up and } \\
\text { frequency of } \\
\text { mea- }\end{array}$ & $\begin{array}{l}\text { Yes, meth- } \\
\text { ods of de- } \\
\text { tection were } \\
\text { described } \\
\text { and out- }\end{array}$ & $\begin{array}{l}\text { Yes, } \\
\text { mean differ- } \\
\text { ence was cal- } \\
\text { culated }\end{array}$ \\
\hline
\end{tabular}

Hypothalamic-pituitary-adrenal (HPA) axis suppression after treatment with glucocorticoid therapy for childhood acute lymphoblastic 


\begin{tabular}{|c|c|c|c|c|c|c|c|c|}
\hline & $\begin{array}{l}\text { authors, the } \\
\text { described } \\
\text { study group } \\
\text { consisted of } \\
\text { more } \\
\text { than } 90 \% \text { of } \\
\text { the original } \\
\text { cohort }\end{array}$ & $\begin{array}{l}\text { group at the } \\
\text { end date of } \\
\text { the study }\end{array}$ & $\begin{array}{l}\text { corticoid } \\
\text { treatment }\end{array}$ & $\begin{array}{l}\text { not taken } \\
\text { into account }\end{array}$ & & $\begin{array}{l}\text { suring were } \\
\text { mentioned }\end{array}$ & $\begin{array}{l}\text { come defini- } \\
\text { tion was ob- } \\
\text { jective and } \\
\text { precise }\end{array}$ & \\
\hline $\begin{array}{l}\text { Kuperman } \\
2001\end{array}$ & $\begin{array}{l}\text { Yes, based } \\
\text { on addi- } \\
\text { tional infor- } \\
\text { mation pro- } \\
\text { vided by the } \\
\text { authors, the } \\
\text { described } \\
\text { study group } \\
\text { consisted of } \\
\text { more } \\
\text { than } 90 \% \text { of } \\
\text { the original } \\
\text { cohort }\end{array}$ & $\begin{array}{l}\text { Yes, out- } \\
\text { come was as- } \\
\text { sessed for } \\
60 \% \text { to } 90 \% \\
\text { of the study } \\
\text { group at the } \\
\text { end date of } \\
\text { the study }\end{array}$ & $\begin{array}{l}\text { Unclear if } \\
\text { outcome as- } \\
\text { sessor } \\
\text { was blinded } \\
\text { to the gluco- } \\
\text { corticoid } \\
\text { treatment }\end{array}$ & $\begin{array}{l}\text { No, impor- } \\
\text { tant prog- } \\
\text { nostic fac- } \\
\text { tors or fol- } \\
\text { low-up were } \\
\text { not taken } \\
\text { into account }\end{array}$ & $\begin{array}{l}\text { No, treat- } \\
\text { ment proto- } \\
\text { col was not } \\
\text { mentioned }\end{array}$ & $\begin{array}{l}\text { Yes, } \\
\text { length of fol- } \\
\text { low-up and } \\
\text { frequency of } \\
\text { mea- } \\
\text { suring were } \\
\text { mentioned }\end{array}$ & $\begin{array}{l}\text { Yes, meth- } \\
\text { ods of de- } \\
\text { tection were } \\
\text { described } \\
\text { and out- } \\
\text { come defini- } \\
\text { tion was ob- } \\
\text { jective and } \\
\text { precise }\end{array}$ & $\begin{array}{l}\text { Yes, } \\
\text { mean differ- } \\
\text { ence was cal- } \\
\text { culated }\end{array}$ \\
\hline $\begin{array}{l}\text { Mahachok- } \\
\text { lertwattana } \\
2004\end{array}$ & $\begin{array}{l}\text { Un- } \\
\text { clear if the } \\
\text { study group } \\
\text { consisted of } \\
\text { more } \\
\text { than } 90 \% \text { of } \\
\text { the original } \\
\text { cohort or if } \\
\text { it was a ran- } \\
\text { dom sample }\end{array}$ & $\begin{array}{l}\text { Yes, out- } \\
\text { come was as- } \\
\text { sessed for } \\
60 \% \text { to } 90 \% \\
\text { of the study } \\
\text { group at the } \\
\text { end date of } \\
\text { the study }\end{array}$ & $\begin{array}{l}\text { Unclear if } \\
\text { outcome as- } \\
\text { sessor } \\
\text { was blinded } \\
\text { to the gluco- } \\
\text { corticoid } \\
\text { treatment }\end{array}$ & $\begin{array}{l}\text { No, impor- } \\
\text { tant prog- } \\
\text { nostic fac- } \\
\text { tors or fol- } \\
\text { low-up were } \\
\text { not taken } \\
\text { into account }\end{array}$ & $\begin{array}{l}\text { Yes, treat- } \\
\text { ment proto- } \\
\text { col and (cu- } \\
\text { mu- } \\
\text { lative) dose, } \\
\text { type, dura- } \\
\text { tion } \\
\text { and form of } \\
\text { cessation } \\
\text { of glucocor- } \\
\text { ticoid treat- } \\
\text { ment were } \\
\text { mentioned }\end{array}$ & $\begin{array}{l}\text { Yes, } \\
\text { length of fol- } \\
\text { low-up and } \\
\text { frequency of } \\
\text { mea- } \\
\text { suring were } \\
\text { mentioned }\end{array}$ & $\begin{array}{l}\text { Yes, meth- } \\
\text { ods of de- } \\
\text { tection were } \\
\text { described } \\
\text { and out- } \\
\text { come defini- } \\
\text { tion was ob- } \\
\text { jective and } \\
\text { precise }\end{array}$ & $\begin{array}{l}\text { Yes, } \\
\text { mean differ- } \\
\text { ence was cal- } \\
\text { culated }\end{array}$ \\
\hline $\begin{array}{l}\text { Petersen } \\
2003\end{array}$ & $\begin{array}{l}\text { Yes, the de- } \\
\text { scribed } \\
\text { study group } \\
\text { consisted of } \\
\text { more } \\
\text { than } 90 \% \text { of } \\
\text { the original } \\
\text { cohort }\end{array}$ & $\begin{array}{l}\text { Yes, out- } \\
\text { come was as- } \\
\text { sessed for } \\
60 \% \text { to } 90 \% \\
\text { of the study } \\
\text { group at the } \\
\text { end date of } \\
\text { the study }\end{array}$ & $\begin{array}{l}\text { Unclear if } \\
\text { outcome as- } \\
\text { sessor } \\
\text { was blinded } \\
\text { to the gluco- } \\
\text { corticoid } \\
\text { treatment }\end{array}$ & $\begin{array}{l}\text { Yes, impor- } \\
\text { tant prog- } \\
\text { nostic fac- } \\
\text { tors or fol- } \\
\text { low-up were } \\
\text { taken into } \\
\text { account }\end{array}$ & $\begin{array}{l}\text { Yes, treat- } \\
\text { ment proto- } \\
\text { col and (cu- } \\
\text { mu- } \\
\text { lative) dose, } \\
\text { type and du- } \\
\text { ration } \\
\text { of glucocor- } \\
\text { ticoid treat- } \\
\text { ment were } \\
\text { mentioned. } \\
\text { Information }\end{array}$ & $\begin{array}{l}\text { Yes, } \\
\text { length of fol- } \\
\text { low-up and } \\
\text { frequency of } \\
\text { mea- } \\
\text { suring were } \\
\text { mentioned }\end{array}$ & $\begin{array}{l}\text { Yes, meth- } \\
\text { ods of de- } \\
\text { tection were } \\
\text { described } \\
\text { and out- } \\
\text { come defini- } \\
\text { tion was ob- } \\
\text { jective and } \\
\text { precise }\end{array}$ & $\begin{array}{l}\text { No, relative } \\
\text { risk, odds ra- } \\
\text { tio, } \\
\text { attributable } \\
\text { risk, } \\
\text { linear or lo- } \\
\text { gistic regres- } \\
\text { sion model, } \\
\text { mean differ- } \\
\text { ence, or Chi } \\
2 \text { statistic }\end{array}$ \\
\hline
\end{tabular}

Hypothalamic-pituitary-adrenal (HPA) axis suppression after treatment with glucocorticoid therapy for childhood acute lymphoblastic 


\begin{tabular}{|c|c|c|c|c|c|c|c|c|}
\hline & & & & & $\begin{array}{l}\text { on the form } \\
\text { of cessation } \\
\text { of glucocor- } \\
\text { ticoid treat- } \\
\text { ment was } \\
\text { based on ad- } \\
\text { di- } \\
\text { tional infor- } \\
\text { mation pro- } \\
\text { vided by the } \\
\text { authors }\end{array}$ & & & $\begin{array}{l}\text { were not cal- } \\
\text { culated }\end{array}$ \\
\hline Rix 2005 & $\begin{array}{l}\text { Yes, the de- } \\
\text { scribed } \\
\text { study group } \\
\text { consisted of } \\
\text { more } \\
\text { than } 90 \% \text { of } \\
\text { the original } \\
\text { cohort }\end{array}$ & $\begin{array}{l}\text { Yes, out- } \\
\text { come was as- } \\
\text { sessed for } \\
60 \% \text { to } 90 \% \\
\text { of the study } \\
\text { group at the } \\
\text { end date of } \\
\text { the study }\end{array}$ & $\begin{array}{l}\text { No, } \\
\text { the outcome } \\
\text { assessor was } \\
\text { not blinded } \\
\text { to the gluco- } \\
\text { corticoid } \\
\text { treatment }\end{array}$ & $\begin{array}{l}\text { Yes, impor- } \\
\text { tant prog- } \\
\text { nostic fac- } \\
\text { tors or fol- } \\
\text { low-up were } \\
\text { taken into } \\
\text { account }\end{array}$ & $\begin{array}{l}\text { Yes, treat- } \\
\text { ment proto- } \\
\text { col and (cu- } \\
\text { mu- } \\
\text { lative) dose, } \\
\text { type and du- } \\
\text { ration } \\
\text { of glucocor- } \\
\text { ticoid treat- } \\
\text { ment were } \\
\text { mentioned. } \\
\text { Information } \\
\text { on the form } \\
\text { of cessation } \\
\text { of glucocor- } \\
\text { ticoid treat- } \\
\text { ment was } \\
\text { based on ad- } \\
\text { di- } \\
\text { tional infor- } \\
\text { mation pro- } \\
\text { vided by the } \\
\text { authors }\end{array}$ & $\begin{array}{l}\text { Yes, } \\
\text { length of fol- } \\
\text { low-up and } \\
\text { frequency of } \\
\text { mea- } \\
\text { suring were } \\
\text { mentioned }\end{array}$ & $\begin{array}{l}\text { Yes, meth- } \\
\text { ods of de- } \\
\text { tection were } \\
\text { described } \\
\text { and out- } \\
\text { come defini- } \\
\text { tion was ob- } \\
\text { jective and } \\
\text { precise }\end{array}$ & $\begin{array}{l}\text { Yes, } \\
\text { mean differ- } \\
\text { ence was cal- } \\
\text { culated }\end{array}$ \\
\hline
\end{tabular}

Table 4. Risk of bias in included randomised controlled trial

\begin{tabular}{|c|c|c|c|c|c|c|}
\hline Study & $\begin{array}{l}\text { Ad- } \\
\text { equate sequence } \\
\text { generation? }\end{array}$ & $\begin{array}{l}\text { Ade- } \\
\text { quate allocation } \\
\text { concealment? }\end{array}$ & Blinding? & $\begin{array}{l}\text { Incomplete out- } \\
\text { come data ad- } \\
\text { dressed? }\end{array}$ & $\begin{array}{l}\text { Free of selective } \\
\text { reporting? }\end{array}$ & $\begin{array}{l}\text { Free of other } \\
\text { bias? }\end{array}$ \\
\hline Einaudi 2008 & $\begin{array}{l}\text { Yes, according to } \\
\text { additional infor- } \\
\text { mation provided } \\
\text { by the authors, } \\
\text { the rule for allo- } \\
\text { cating interven- }\end{array}$ & $\begin{array}{l}\text { Yes, according to } \\
\text { additional infor- } \\
\text { mation provided } \\
\text { by the authors, } \\
\text { the randomisa- } \\
\text { tion method did }\end{array}$ & $\begin{array}{l}\text { Based on ad- } \\
\text { ditional informa- } \\
\text { tion provided by } \\
\text { the authors, care } \\
\text { providers, } \\
\text { patients and out- }\end{array}$ & $\begin{array}{l}\text { Yes, there are no } \\
\text { missing outcome } \\
\text { data }\end{array}$ & $\begin{array}{l}\text { No, "adrenal } \\
\text { func- } \\
\text { tion completely } \\
\text { recovered in the } \\
12 \text { children eval- } \\
\text { uated with sub- }\end{array}$ & Yes \\
\hline
\end{tabular}




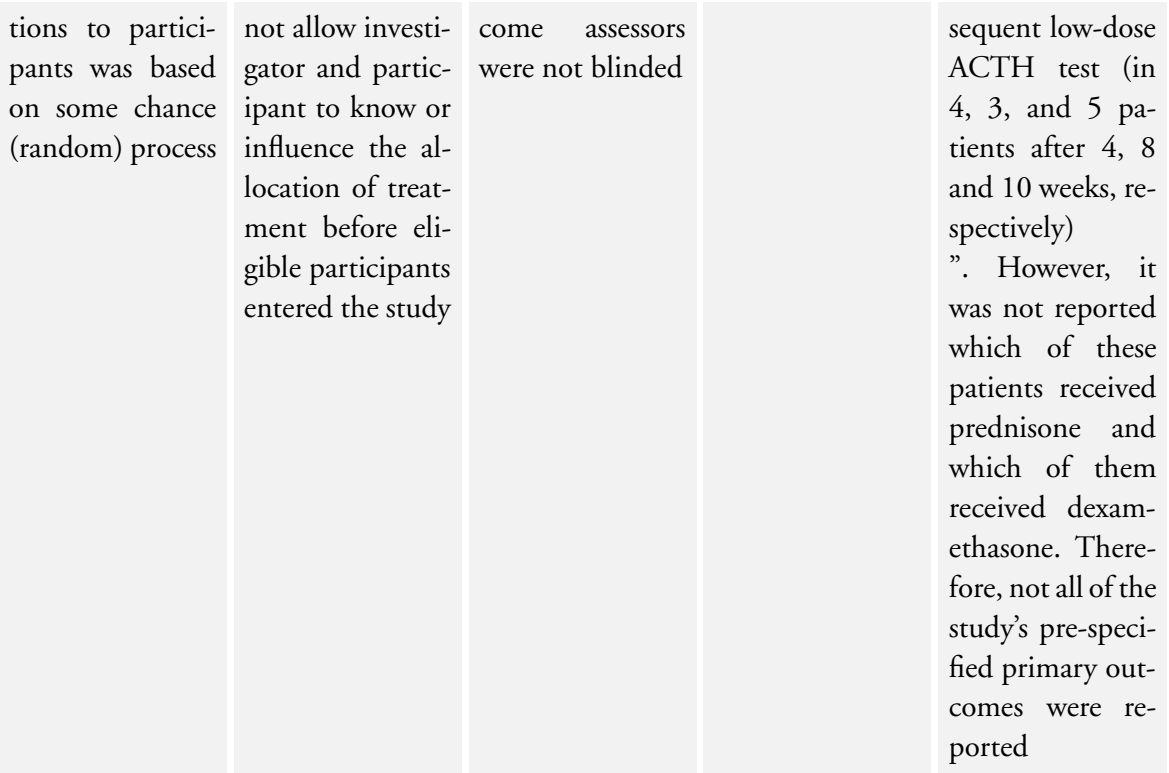

Table 5. Prevalence and duration of adrenal insufficiency evaluated by an ACTH stimulation test

Felner et al. Therapy: dexamethasone (cumulative dose $168 \mathrm{mg} / \mathrm{m}^{2}$ )

\begin{tabular}{lllll}
\hline Time after cessation & Before & 1 day & 4 weeks & 8 weeks \\
\hline $\mathrm{n}$ insufficient/n total & $0 / 10$ & $10 / 10$ & $3 / 10$ & $0 / 10$ \\
\hline Petersen et al. (1) & Therapy: prednisolone (cumulative dose $\left.2257.5 \mathrm{mg} / \mathrm{m}^{2}\right)^{a}$ \\
\hline Time after cessation & 1 week & 3 weeks & 7 weeks & End of follow-up: $10,11,11$ and 19 weeks, respectively \\
\hline $\mathrm{n}$ insufficient/n total & $7 / 10$ & $6 / 10$ & $4 / 10$ & $4 / 10$ \\
\hline
\end{tabular}

Petersen et al. (2) Therapy: dexamethasone (cumulative dose $\left.236.25 \mathrm{mg} / \mathrm{m}^{2}\right)^{b}$

\begin{tabular}{llllll}
\hline Time after cessation & 1 week & 3 weeks & 7 weeks & End of follow-up: 16, 33 and 34 weeks, respectively \\
\hline $\mathrm{n}$ insufficient/n total & $5 / 7$ & $4 / 7$ & $3 / 7$ & $2 / 7$ \\
\hline
\end{tabular}

${ }^{a}$ One patient received additional $840 \mathrm{mg} / \mathrm{m}^{2}$ prednisolone during the period of adrenal insufficiency.

${ }^{b}$ These patients received prednisolone $2257.5 \mathrm{mg} / \mathrm{m}^{2}$ as induction therapy before. Three high-risk patients received additional 560 $\mathrm{mg} / \mathrm{m}^{2}$ prednisolone in advance. One patient received additional $420 \mathrm{mg} / \mathrm{m}^{2}$ prednisolone during the period of adrenal insufficiency and two patients received additional $1260 \mathrm{mg} / \mathrm{m}^{2}$ prednisolone during the period of adrenal insufficiency. 
Table 6. Prevalence and duration of adrenal insufficiency evaluated by a low-dose ACTH stimulation test

Mahachoklertwat- Therapy: prednisolone (cumulative dose $\left.1120 \mathrm{mg} / \mathrm{m}^{2}\right)^{a}$ tana et al.

\begin{tabular}{|c|c|c|c|c|c|}
\hline Time after cessation & 2 weeks & 4 weeks & 8 weeks & 12 weeks & 20 weeks \\
\hline $\begin{array}{l}\mathrm{n} \text { insufficient/n to- } \\
\text { tal }\end{array}$ & $11 / 24$ & $9 / 24$ & $7 / 24$ & $3 / 24$ & $3 / 24$ \\
\hline Rix et al. (1) & \multicolumn{5}{|c|}{ Therapy: prednisolone (cumulative dose $2257.5 \mathrm{mg} / \mathrm{m}^{2}$ ) } \\
\hline Time after cessation & Before & 1 day & 3 days & 5 days & \\
\hline $\begin{array}{l}\mathrm{n} \text { insufficient } / \mathrm{n} \text { to- } \\
\text { tal }\end{array}$ & $0 / 13$ & $16 / 17$ & $8 / 15$ & $8 / 17$ & \\
\hline Rix et al. (2) & \multicolumn{5}{|c|}{ Therapy: prednisolone (cumulative dose $\left.420 \mathrm{mg} / \mathrm{m}^{2}\right)^{b}$} \\
\hline Time after cessation & Before & 2 days & & & \\
\hline $\begin{array}{l}\mathrm{n} \text { insufficient/n to- } \\
\text { tal }\end{array}$ & $2 / 13$ & $13 / 13$ & & & \\
\hline
\end{tabular}

Rix et al. (3) Therapy: dexamethasone (cumulative dose $\left.236.25 \mathrm{mg} / \mathrm{m}^{2}\right)^{b}$

\begin{tabular}{l|lll|l}
\hline Time after cessation & Before & 1 day & 3 days & 7 days \\
\hline $\begin{array}{l}\mathrm{n} \text { insufficient/n to- } \\
\text { tal }\end{array}$ & $0 / 5$ & $2 / 2$ & $3 / 5$ & $1 / 5$ \\
\hline
\end{tabular}

Einaudi et al. (1) Therapy: prednisolone (cumulative dose $\left.1477.5 \mathrm{mg} / \mathrm{m}^{2}\right)^{c}$

\begin{tabular}{lllllll}
\hline Time after cessation & 1 day & 7 to 14 days & 28 days & 42 days & 10 weeks \\
\hline $\begin{array}{l}\mathrm{n} \text { insufficient/n to- } \\
\text { tal }\end{array}$ & $82 / 40$ & $8 / 32$ & $5 / 8$ & $5 / 5$ & $0 / 5$ \\
\hline
\end{tabular}

Einaudi et al. (2) Therapy: dexamethasone (cumulative dose $\left.246.25 \mathrm{mg} / \mathrm{m}^{2}\right)^{c}$

\begin{tabular}{lllllll}
\hline Time after cessation & 1 day & 7 to 14 days & 28 days & 42 days & 10 weeks \\
\hline $\begin{array}{l}\text { n insufficient/n to- } \\
\text { tal }\end{array}$ & $4 / 20 / 24$ & $3 / 4$ & $3 / 3$ & $0 / 3$ \\
\hline
\end{tabular}

${ }^{a}$ Four weeks after completion of the induction therapy, the patients received maintenance therapy consisting of a 7-day course of highdose dexamethasone $8 \mathrm{mg} / \mathrm{m}^{2} /$ day, every 4 weeks. The cumulative dose depended on how long the patient had been followed up.

${ }^{b}$ All patients first received prednisolone (cumulative dose $2257.5 \mathrm{mg} / \mathrm{m}^{2}$ ).

${ }^{c}$ After 7 days of prednisone $\left(60 \mathrm{mg} / \mathrm{m}^{2} /\right.$ day, cumulative dose: $\left.420 \mathrm{mg} / \mathrm{m}^{2}\right)$. 
Table 7. Prevalence and duration of adrenal insufficiency evaluated by basal morning cortisol values

\begin{tabular}{|c|c|c|c|}
\hline Cunha et al. & \multicolumn{3}{|c|}{ No data on patient level were available } \\
\hline \multicolumn{4}{|l|}{ Time after cessation } \\
\hline \multicolumn{4}{|l|}{$\mathrm{n}$ insufficient $/ \mathrm{n}$ total } \\
\hline Kuperman et al. & \multicolumn{3}{|c|}{ Therapy: dexamethasone (cumulative dose $\left.252 \mathrm{mg} / \mathrm{m}^{2}\right)^{a}$} \\
\hline Time after cessation & Before & 1 week & 2 weeks \\
\hline $\mathrm{n}$ insufficient $/ \mathrm{n}$ total & $0 / 15$ & $4 / 15$ & $4 / 14$ \\
\hline
\end{tabular}

${ }^{a}$ Results based on basal cortisol levels; cut-off level $7 \mu \mathrm{g} / \mathrm{dL}=194 \mathrm{nmol} / \mathrm{L}$.

\section{A P P E N D I C E S}

\section{Appendix I. Search strategy for PubMed}

1. For children the following MeSH headings and text words were used: infant OR infan* OR newborn OR newborn* OR new-born* OR baby OR baby* OR babies OR neonat* OR perinat* OR postnat* OR child OR child* OR schoolchild* OR schoolchild OR school child OR school child* OR kid OR kids OR toddler* OR adolescent OR adoles* OR teen* OR boy* OR girl* OR minors OR minors* OR underag* OR under ag* OR juvenil* OR youth* OR kindergar* OR puberty OR puber* OR pubescen* OR prepubescen* OR prepuberty* OR pediatrics OR pediatric* OR paediatric* OR peadiatric* OR schools OR nursery school* OR preschool* OR pre school* OR primary school* OR secondary school* OR elementary school* OR elementary school OR high school* OR highschool* OR school age OR schoolage OR school age* OR schoolage* OR infancy OR schools, nursery OR infant, newborn

2. For acute lymphocytic leukemia the following MeSH headings and text words were used: acute lymphocytic leukemia OR childhood ALL OR Precursor Cell Lymphoblastic Leukemia-Lymphoma OR Precursor Cell Lymphoblastic Leukemia Lymphoma OR Leukemia, Lymphoblastic OR Leukemia, Lymphoblastic, Acute OR Leukemia, Lymphocytic, Acute OR Leukemia, Lymphoid, Acute OR Lymphoblastic Leukemia, Acute OR Acute Lymphoblastic Leukemia OR Leukemia, Acute Lymphoblastic OR Lymphoblastic Lymphoma OR Lymphomas, Lymphoblastic OR Lymphocytic Leukemia, Acute OR Acute Lymphocytic Leukemia OR Leukemia, Acute Lymphocytic OR Lymphoma, Lymphoblastic OR Acute Lymphoid Leukemia OR Leukemia, Acute Lymphoid OR Lymphoid Leukemia, Acute OR Lymphoblastic Leukemia OR Leukemia, Lymphocytic, Acute, L1 OR Lymphocytic Leukemia, L1 OR L1 Lymphocytic Leukemia OR Leukemia, L1 Lymphocytic OR Lymphoblastic Leukemia, Acute, Childhood OR Lymphoblastic Leukemia, Acute, L1 OR ALL, Childhood OR Childhood ALL OR Leukemia, Lymphoblastic, Acute, L1 OR Leukemia, Lymphocytic, Acute, L2 OR Lymphocytic Leukemia, L2 OR L2 Lymphocytic Leukemia OR Leukemia, L2 Lymphocytic OR Lymphoblastic Leukemia, Acute, Adult OR Lymphoblastic Leukemia, Acute, L2 OR Leukemia, Lymphoblastic, Acute, L2 OR Leukemia, Lymphoblastic, Acute, Philadelphia-Positive OR ((akut* OR acut*) AND ((leukemi* OR leukaemi*) OR (lymphocyt* OR lymphoblast*)))

3. For glucocorticoids the following MeSH headings and text words were used:

Steroid OR steroids OR steroid* OR glucocorticoid OR glucocorticoids OR glucocorticoid* OR corticoid OR corticoids OR corticoid* OR adrenal cortex hormones OR hormones, adrenal cortex OR

prednison OR prednisone OR 53-03-2 OR Dehydrocortisone OR delta-Cortisone OR Winpred OR ICN Brand of Prednisone OR Cortancyl OR Panafcort OR Aventis Brand of Prednisone OR Cutason OR mibe Brand of Prednisone OR Dacortin OR Merck Brand of Prednisone OR Decortin Brand of Prednisone OR Decortisyl OR Hoechst Brand of Prednisone OR Deltasone OR Pharmacia Brand

Hypothalamic-pituitary-adrenal (HPA) axis suppression after treatment with glucocorticoid therapy for childhood acute lymphoblastic 26 leukaemia (Review)

Copyright $\Subset 2012$ The Cochrane Collaboration. Published by John Wiley \& Sons, Ltd. 
of Prednisone OR Encortone OR Encorton OR Enkortolon OR Kortancyl OR Liquid Pred OR Meticorten OR Schering-Plough Brand of Prednisone OR Orasone OR Solvay Brand of Prednisone OR Panasol OR Seatrace Brand of Prednisone OR Predni Tablinen OR Lichtenstein Brand of Prednisone OR Prednidib OR Diba Brand of Prednisone OR Predniment OR Ferring Brand of Prednisone OR Prednison acsis OR acis Brand of Prednisone OR Prednison Galen OR GALENpharma Brand of Prednisone OR Prednison Hexal OR Hexal Brand of Prednisone OR Pronisone OR Rectodelt OR Trommsdorff Brand of Prednisone OR Ultracorten OR Sone OR Fawns \& McAllan Brand of Prednisone OR Sterapred OR Merz Brand of Prednisone OR Apo-Prednisone OR Apotex Brand of Prednisone OR Cortan OR Halsey Drug Brand of Prednisone OR prednisolon OR 50-24-8 OR dexamethason OR dexametasone OR dexamethasone OR 50-02-2 OR Methylfluorprednisolone OR Hexadecadrol OR Maxidex OR Alcon Brand of Dexamethasone OR Dexamethasone Intensol OR Roxane Brand of Dexamethasone OR Decaject OR Merz Brand 1 of Dexamethasone OR Oradexon OR Decameth OR Foy Brand of Dexamethasone OR Decaspray OR Merck Brand of Dexamethasone OR Dexasone OR ICN Brand of Dexamethasone OR Hexadrol OR Millicorten OR Dexpak OR ECR Brand of Dexamethasone OR Decaject-L.A. OR Decaject L.A. OR Merz Brand 2 of Dexamethasone

4. For HPA function the following MeSH headings and text words were used:

HPA OR HPA axis OR hypothalamic-pituitary-adrenal OR hypothalamic-pituitary-adrenal axis OR adrenal insufficiency OR adrenal axis OR Hypothalamo-Hypophyseal System OR hypothalamic insufficiency OR pituitary OR Pituitary-Adrenal Function Tests OR Function Test, Pituitary-Adrenal OR Function Tests, Pituitary-Adrenal OR Pituitary Adrenal Function Tests OR Pituitary-Adrenal Function Test OR Test, Pituitary-Adrenal Function OR Tests, Pituitary-Adrenal Function OR Pituitary-Adrenal System OR Pituitary Adrenal System OR Pituitary-Adrenal Systems OR System, Pituitary-Adrenal OR Systems, Pituitary-Adrenal OR

hypothalamus OR hypothalam* OR hypophysis OR hypophys* OR Hypothalamo-Hypophyseal OR Pituitary Gland OR Pituitary Glands OR Hypothalamic Hormones OR Hormones, Hypothalamic OR Hypothalamic Pituitary-Regulating Peptides OR Hypothalamic Pituitary Regulating Peptides OR Peptides, Hypothalamic Pituitary-Regulating OR Pituitary-Regulating Peptides, Hypothalamic OR Hypothalamic Pituitary-Regulating Hormones OR Hormones, Hypothalamic Pituitary-Regulating OR Hypothalamic Pituitary Regulating Hormones OR Pituitary-Regulating Hormones, Hypothalamic OR Pituitary Hormones OR Hormones, Pituitary OR adrenal glands OR

adrenal function test[all fields] OR adrenal function tests[all fields] OR adrenal function testing [all fields] OR adrenal function evaluation[all fields] OR ACTH stimulation test[all fields] OR ACTH stimulation tests[all fields] OR ACTH stimulation testing [all fields] OR ACTH test[all fields] OR ACTH tests[all fields] OR ACTH testing [all fields] OR ACTH evaluation[all fields] OR CRH stimulation test[all fields] OR CRH stimulation tests[all fields] OR CRH stimulation testing [all fields] OR CRH test[all fields] OR CRH tests[all fields] OR CRH testing [all fields] OR CRH evaluation[all fields] OR glucagon stimulation test[all fields] OR glucagon stimulation tests[all fields] OR glucagon stimulation testing [all fields] OR glucagon test [all fields] OR glucagon tests[all fields] OR glucagon testing [all fields] OR glucagon evaluation[all fields] OR fasting cortisol OR morning cortisol

Final search: 1 AND 2 AND 3 AND 4

${ }^{*}=1$ or more characters $]$

\section{Appendix 2. Search strategy for EMBASE (Ovid)}

1. For children the following Emtree terms and text words were used:

1. infant/ or infancy/ or newborn/ or baby/ or child/ or preschool child/ or school child/

2. adolescent/ or juvenile/ or boy/ or girl/ or puberty/ or prepuberty/ or pediatrics/

3. primary school/ or high school/ or kindergarten/ or nursery school/ or school/

4. or/1-3

5. (infant $\$$ or newborn $\$$ or (new adj born $\$$ ) or baby or baby $\$$ or babies or neonate $\$$ or perinat $\$$ or postnat $\$$ ).mp.

6. (child $\$$ or (school adj child\$) or schoolchild $\$$ or (school adj age $\$$ ) or schoolage $\$$ or (pre adj school\$) or preschool\$).mp.

7. (kid or kids or toddler $\$$ or adoles $\$$ or teen $\$$ or boy $\$$ or girl $\$$ ).mp.

8. (minors\$ or (under adj ag\$) or underage $\$$ or juvenil $\$$ or youth $\$$ ).mp.

9. (puber $\$$ or pubescen $\$$ or prepubescen $\$$ or prepubert $\$$ ).mp.

10. (pediatric $\$$ or paediatric $\$$ or peadiatric $\$$ ).mp.

11. (school or schools or (high adj school\$) or highschool $\$$ or (primary adj school\$) or (nursery adj school\$) or (elementary adj school) or (secondary adj school\$) or kindergar\$).mp.

12. or $/ 5-11$

13. 4 or 12

2. For acute lymphocytic leukemia the following Emtree terms and text words were used:

1. acute lymphocytic leukemia.mp. or exp Acute Lymphocytic Leukemia/

Hypothalamic-pituitary-adrenal (HPA) axis suppression after treatment with glucocorticoid therapy for childhood acute lymphoblastic 
2. (childhood adj ALL).

3. precursor cell lymphoblastic leukemia-lymphoma.mp. or exp Acute Lymphoblastic Leukemia/

4. lymphoblastic lymphoma.mp. or exp Lymphoblastoma/

5. (acute lymphoblastic leukemia or acute lymphoid leukemia).mp.

6. lymphoblastic leukemia.mp. or exp Lymphatic Leukemia/

7. (L1 lymphocytic leukemia or L2 lymphocytic leukemia).mp.

8. (lymphoblastic lymphoma or lymphoblastic lymphomas).mp. or exp lymphatic leukemia/

9. childhood acute lymphoblastic leukemia.mp. or exp Childhood Leukemia/

10. philadelphia positive acute lymphoblastic leukemia.mp.

11. ((akut $\$$ or acut $\$)$ and (leukemi $\$$ or leukaemi $\$$ or lymphocyt $\$$ or lymphoblast $\$)$ ).mp.

12. or/1-11

3. For glucocorticoids the following Emtree terms and text words were used:

1. steroid.mp. or exp steroid/

2. (steroids or steroid\$).mp.

3. glucocorticoid.mp. or exp glucocorticoid/

4. (glucocorticoids or glucocorticoid\$).mp.

5. corticoid.mp. or exp corticosteroid/

6. (corticoids or corticoid\$).mp.

7. adrenal cortex hormones.mp.

8. prednison.mp. or exp prednisone/

9. prednisone.mp.

10. 53-03-2.rn.

11. (dehydrocortisone or delta-cortisone or winpred or cortancyl or panafcort or cutason or dacortin or decortisyl).mp.

12. (deltasone or encortone or encorton or emkortolon or kortancyl or meticorten).mp.

13. (orasone or panasol or predni tablinen or prednidib or predniment or prednison acsis).mp.

14. (prednison galen or prednison hexal or pronisone or rectodelt or ultracorten or sone).mp.

15. (sterapred or apo-prednisone or cortan or prednisolon).mp.

16. 50-24-8.rn.

17. exp dexamethasone/

18. (dexamethason or dexamethasone or dexametasone).mp.

19. 50-02-2.rn.

20. (methylfluorprednisolone or hexadecadrol or maxidex or dexamethasone intensol).mp.

21. (decaject or oradexon or decameth or decaspray or dexasone or hexadrol or millicorten or dexpak or decaject-la or decaject la).mp.

22. or/1-21

4. For HPA function the following Emtree terms and text words were used:

1. exp hypothalamus hypophysis adrenal system/

2. (HPA or HPA axis).mp.

3. (hypothalamic-pituitary-adrenal or hypothalamic-pituitary-adrenal axis).mp.

4. adrenal insufficiency.mp. or exp adrenal insufficiency/

5. adrenal axis.mp.

6. hypothalamo-hypophyseal system.mp. or exp hypothalamus hypophysis system/

7. hypothalamic insufficiency.mp.

8. pituitary.mp.

9. (pituitary-adrenal function tests or pituitary-adrenal function test).mp.

10. (pituitary adrenal function tests or pituitary adrenal function test).mp.

11. (pituitary adrenal system or pituitary-adrenal system or pituitary adrenal systems or pituitary-adrenal systems).mp.

12. exp hypothalamus/ or hypothalamus.mp.

13. hypothalam $\$ . m p$.

14. exp hypophysis/ or hypophysis.mp.

15. hypophys\$.mp.

16. exp hypothalamus hypophysis system/ or hypothalamo-hypophyseal.mp.

17. (pituitary gland or pituitary glands).mp.

18. hypothalamic hormones.mp. or exp hypothalamus hormone/

Hypothalamic-pituitary-adrenal (HPA) axis suppression after treatment with glucocorticoid therapy for childhood acute lymphoblastic 
19. (hypothalamic pituitary-regulating peptides or hypothalamic pituitary regulating peptides).mp.

20. (hypothalamic pituitary-regulating hormones or hypothalamic pituitary regulating hormones).mp.

21. pituitary hormones.mp. or exp hypophysis hormone/

22. adrenal glands.mp. or exp adrenal gland/

23. adrenal function test.mp. or exp endocrine function test/

24. (adrenal function test or adrenal function testing or adrenal function evaluation).mp.

25. ACTH stimulation test.mp. or exp corticotropin test/

26. (ACTH stimulation tests or ACTH stimulation testing).mp.

27. (ACTH test or ACTH tests or ACTH testing or ACTH evaluation).mp.

28. (CRH stimulation test or CRH stimulation tests or $\mathrm{CRH}$ stimulation testing).mp.

29. (CRH test or CRH tests or CRH testing or CRH evaluation).mp.

30. (glucagon stimulation test or glucagon stimulation tests or glucagon stimulation testing).mp.

31. (glucagon test or glucagon tests or glucagon testing or glucagon evaluation).mp.

32. (fasting cortisol or morning cortisol).mp.

33. or/ $1-32$

Final search: 1 AND 2 AND 3 AND 4

$[\mathrm{mp}=$ title, abstract, subject headings, heading word, drug trade name, original title, device manufacturer, drug manufacturer name; $\$$

= 1 or more characters; / = Emtree term; $\mathrm{rn}$ = registry number]

\section{Appendix 3. Search strategy for the Cochrane Central Register of Controlled Trials (CENTRAL)}

1. For children the following text words were used:

(infant OR infan* OR newborn OR newborn* OR new-born* OR baby OR baby* OR babies OR neonat* OR child OR child* OR schoolchild* OR schoolchild OR school child OR school child* OR kid OR kids OR toddler* OR adolescent OR adoles* OR teen* OR boy* OR girl* OR minors OR minors* OR underag* OR under ag* OR juvenil* OR youth* OR kindergar* OR puberty OR puber* OR pubescen* OR prepubescen* OR prepuberty* OR pediatrics OR pediatric* OR paediatric* OR peadiatric* OR schools OR nursery school* OR preschool* OR pre school* OR primary school* OR secondary school* OR elementary school* OR elementary school OR high school* OR highschool* OR school age OR schoolage OR school age* OR schoolage* OR infancy)

2. For acute lymphocytic leukemia the following text words were used:

acute lymphocytic leukemia OR childhood ALL OR Precursor Cell Lymphoblastic Leukemia-Lymphoma OR Precursor Cell Lymphoblastic Leukemia Lymphoma OR Acute Lymphoblastic Leukemia OR Lymphoblastic Lymphoma OR Acute Lymphocytic Leukemia OR Acute Lymphoid Leukemia OR Lymphoblastic Leukemia OR L1 Lymphocytic Leukemia OR L2 Lymphocytic Leukemia OR ((akut* OR acut*) AND (leukemi* OR leukaemi*) OR (lymphocyt* OR lymphoblast*))

3. For glucocorticoids the following text words were used:

Steroid OR steroids OR steroid* OR glucocorticoid OR glucocorticoids OR glucocorticoid* OR corticoid OR corticoids OR corticoid* OR adrenal cortex hormones OR prednison OR prednisone OR Dehydrocortisone OR delta-Cortisone OR Winpred OR ICN Brand of Prednisone OR Cortancyl OR Panafcort OR Aventis Brand of Prednisone OR Cutason OR mibe Brand of Prednisone OR Dacortin OR Merck Brand of Prednisone OR Decortin Brand of Prednisone OR Decortisyl OR Hoechst Brand of Prednisone OR Deltasone OR Pharmacia Brand of Prednisone OR Encortone OR Encorton OR Enkortolon OR Kortancyl OR Liquid Pred OR Meticorten OR Schering-Plough Brand of Prednisone OR Orasone OR Solvay Brand of Prednisone OR Panasol OR Seatrace Brand of Prednisone OR Predni Tablinen OR Lichtenstein Brand of Prednisone OR Prednidib OR Diba Brand of Prednisone OR Predniment OR Ferring Brand of Prednisone OR Prednison acsis OR acis Brand of Prednisone OR Prednison Galen OR GALENpharma Brand of Prednisone OR Prednison Hexal OR Hexal Brand of Prednisone OR Pronisone OR Rectodelt OR Trommsdorff Brand of Prednisone OR Ultracorten OR Sone OR Fawns \& McAllan Brand of Prednisone OR Sterapred OR Merz Brand of Prednisone OR Apo-Prednisone OR Apotex Brand of Prednisone OR Cortan OR Halsey Drug Brand of Prednisone OR prednisolon OR dexamethason OR dexametasone OR dexamethasone OR Methylfluorprednisolone OR Hexadecadrol OR Maxidex OR Alcon Brand of Dexamethasone OR Dexamethasone Intensol OR Roxane Brand of Dexamethasone OR Decaject OR Merz Brand 1 of Dexamethasone OR Oradexon OR Decameth OR Foy Brand of Dexamethasone OR Decaspray OR Merck Brand of Dexamethasone OR Dexasone OR ICN Brand of Dexamethasone OR Hexadrol OR Millicorten OR Dexpak OR ECR Brand of Dexamethasone OR Decaject-L.A. OR Decaject L.A. OR Merz Brand 2 of Dexamethasone

4. For HPA function the following text words were used:

HPA OR HPA axis OR hypothalamic-pituitary-adrenal OR hypothalamic-pituitary-adrenal axis OR adrenal insufficiency OR adrenal axis OR Hypothalamo-Hypophyseal System OR hypothalamic insufficiency OR pituitary OR Pituitary-Adrenal Function Tests OR

Hypothalamic-pituitary-adrenal (HPA) axis suppression after treatment with glucocorticoid therapy for childhood acute lymphoblastic 29 leukaemia (Review)

Copyright @ 2012 The Cochrane Collaboration. Published by John Wiley \& Sons, Ltd. 
Pituitary Adrenal Function Tests OR Pituitary-Adrenal Function Test OR Pituitary-Adrenal System OR Pituitary Adrenal System OR Pituitary-Adrenal Systems OR hypothalamus OR hypothalam* OR hypophysis OR hypophys* OR Hypothalamo-Hypophyseal OR Pituitary Gland OR Pituitary Glands OR Hypothalamic Hormones OR Hypothalamic Pituitary-Regulating Peptides OR Hypothalamic Pituitary Regulating Peptides OR Hypothalamic Pituitary-Regulating Hormones OR Hypothalamic Pituitary Regulating Hormones OR Pituitary Hormones OR adrenal glands OR adrenal function test OR adrenal function tests OR adrenal function testing OR adrenal function evaluation OR ACTH stimulation test OR ACTH stimulation tests OR ACTH stimulation testing OR ACTH test OR ACTH tests OR ACTH testing OR ACTH evaluation OR CRH stimulation test OR CRH stimulation tests OR CRH stimulation testing OR CRH test OR CRH tests OR CRH testing OR CRH evaluation OR glucagon stimulation test OR glucagon stimulation tests OR glucagon stimulation testing OR glucagon test OR glucagon tests OR glucagon testing OR glucagon evaluation OR fasting cortisol OR morning cortisol

Final search: 1 and 2 and 3 and 4

The search was performed in title, abstract or keywords.

\section{Appendix 4. Search strategy for conference proceedings}

Search used in the International Society of Paediatric Oncology (SIOP) proceedings:

(http://www.siop.nl)

Separate searches were done for the following search terms:

HPA

HPA axis

adrenal

hypothalamus

hypothalamic-pituitary-adrenal

Search used in American Society of Clinical Oncology (ASCO) proceedings:

(http://www.asco.org)

Only annual meetings were searched (since molecular markers, breast, genitourinary, gastrointestinal and prostate specific meetings were not expected to yield results that involved HPA axis suppression during acute lymphoblastic leukemia).

Separate searches were done for the following search terms:

HPA

HPA axis

adrenal

hypothalamus

hypothalamic-pituitary-adrenal

The search was performed in title field.

\section{Appendix 5. Search strategy for ongoing trials registers}

Search used in the International Standard Randomized Controlled Trial Number (ISRCTN) register and the National Institutes of Health (NIH) register for ongoing trials:

(http://www.controlled-trials.com)

Separate searches were done for the following search terms:

HPA

HPA axis

adrenal

hypothalamus

hypothalamic-pituitary-adrenal

The search was performed in title field.

Hypothalamic-pituitary-adrenal (HPA) axis suppression after treatment with glucocorticoid therapy for childhood acute lymphoblastic 


\section{H I S T O R Y}

Protocol first published: Issue 10, 2010

Review first published: Issue 5, 2012

\section{CONTRIBUTIONSOFAUTHORS}

Maartje Gordijn designed the study and wrote the protocol. Together with Edith Leclercq, Trials Search coordinator, she developed the search strategy. She identified the studies meeting inclusion criteria. She searched for unpublished and ongoing studies. She performed the data extraction and 'Risk of bias' assessment of the included studies. She analysed the data and interpreted the results. She wrote and revised the manuscript.

Reinoud Gemke and Gertjan Kaspers identified the studies meeting the inclusion criteria and checked the data extraction and the risk of bias assessment of the included studies. They contributed to the interpretation of the results. They critically reviewed the protocol and the manuscript.

Joost Rotteveel contributed to the interpretation of the results. He critically reviewed the protocol and the manuscript.

Elvira van Dalen contributed to the design of the study and the protocol. She contributed to the analysis of the data and the interpretation of the results. She critically reviewed the manuscript.

All authors have approved the final report.

\section{DECLARATIONSOF INTEREST}

None.

\section{SOURCESOFS UPPORT}

\section{Internal sources}

- No sources of support supplied

\section{External sources}

- Dutch Cancer Society, Netherlands.

- Foundation Children Cancer-free (KiKa), Netherlands.

\section{DIFFERENCES BETWEEN PROTOCOLANDREVIEW}

In addition to the primary objective stated in the protocol to examine the occurrence of HPA axis suppression after treatment with glucocorticoids for childhood ALL, we have also studied the duration of HPA axis suppression.

The data extraction and the 'Risk of bias' assessment of the included studies were performed by one review author and were independently checked by two other review authors (as opposed to the protocol, where it was stated that two independent review authors would do this).

Hypothalamic-pituitary-adrenal (HPA) axis suppression after treatment with glucocorticoid therapy for childhood acute lymphoblastic 


\section{INDEX TERMS}

\section{Medical Subject Headings (MeSH)}

Adrenal Insufficiency [ ${ }^{*}$ chemically induced]; Antineoplastic Agents, Hormonal [administration \& dosage; adverse effects]; Cohort Studies; Dexamethasone [administration \& dosage; adverse effects]; Glucocorticoids [administration \& dosage; *adverse effects]; Hypothalamo-Hypophyseal System [*drug effects]; Pituitary-Adrenal System [*drug effects]; Precursor Cell Lymphoblastic LeukemiaLymphoma [*drug therapy]; Prednisolone [administration \& dosage; adverse effects]; Randomized Controlled Trials as Topic

\section{MeSH check words}

Child; Humans 